DOE/NV/13609--09

\title{
MEASUREMENTS OF PLUTONIUM AND AMERICIUM IN SOIL SAMPLES FROM PROJECT 57 USING THE SUSPENDED SOIL PARTICLE SIZING SYSTEM (SSPSS)
}

\author{
prepared by \\ John L. Bowen, Rowena Gonzalez and David S. Shafer
}

submitted to

Nevada Operations Office

National Nuclear Security Administration

U.S. Department of Energy

Las Vegas, Nevada

MAY 2001

Publication No. 45182 
Reference herein to any specific commercial product, process, or service by trade name, trademark, manufacturer, or otherwise, does not necessarily constitute or imply its endorsement, recommendation, or favoring by the United States Government or any agency thereof or its contractors or subcontractors. The views and opinions of authors expressed herein do not necessarily state or reflect those of the United States Government or any agency thereof.

This report has been reproduced directly from the best available copy.

Available for sale to the public, in paper, from:

U.S. Department of Commerce

National Technical Information Service

5285 Port Royal Rd.

Springfield, VA 22161

phone: 800.553 .6847

fax: 703.605.6000

email: order@ntis.fedworld.gov

online ordering: http://www.ntis.gov/ordering.htm

Available electronically at http://www.doe.gov/bridge

Available for a processing fee to the U.S. Department of Energy and its contractors, in paper, from:

U.S. Department of Energy

Office of Scientific and Technical Information

P.O. Box 62

Oak Ridge, TN 37831-0062

phone: 423.576 .8401

fax: 423.576 .5728

email: reports@adonis.osti.gov 
DOE/NV/13609--09

\title{
MEASUREMENTS OF PLUTONIUM AND AMERICIUM IN SOIL SAMPLES FROM PROJECT 57 USING THE SUSPENDED SOIL PARTICLE SIZING SYSTEM (SSPSS)
}

\author{
Prepared by \\ John L. Bowen \\ Division of Atmospheric Sciences \\ Rowena Gonzalez \\ Harry Reid Center for Environmental Studies \\ University of Nevada, Las Vegas \\ David S. Shafer \\ Division of Hydrologic Sciences \\ Desert Research Institute \\ University and Community College System of Nevada
}

Publication No. 45181

\author{
Submitted to \\ Nevada Operations Office \\ National Nuclear Security Administration \\ U.S. Department of Energy \\ Las Vegas, Nevada
}

May 2001

The work upon which this report is based was supported by the U.S. Department of Energy under Contract \#DE-AC08-00NV13609. Approved for public release; further dissemination unlimited 


\section{EXECUTIVE SUMMARY}

As part of the preliminary site characterization at Project 57, soil samples were collected for separation into several size-fractions using the Suspended Soil Particle Sizing System (SSPSS), designed and fabricated by the Division of Atmospheric Sciences (DAS) of the Desert Research Institute (DRI). SSPSS operations, consisting of particle separation by sieving and aerodynamic sizing, were performed by personnel of the Harry Reid Center for Environmental Studies (HRC) at the University of Nevada, Las Vegas (UNLV).

Soil samples were collected specifically for separation by the SSPSS at three general locations in the deposited Project 57 plume, the projected radioactivity of which ranged from 100 to $600 \mathrm{pCi} / \mathrm{g}$. The primary purpose in focusing on samples with this level of activity is that it would represent anticipated residual soil contamination remaining at the site after corrective actions are completed. Consequently, the results of the SSPSS analysis can contribute to dose calculation and corrective action-level determinations for future land-use scenarios at the site. Higher activity soils were also not considered because of restrictions on the amount of radioactive material that UNLV is licensed to have in its possession. Soil samples were collected at five sites for each of the three locations. At each sample site, vegetation and debris were removed and soil was collected to a depth of approximately $8 \mathrm{~cm}$, placed in a 2-liter container, and marked with a sample identification number. At two of the sample sites, a second soil sample was collected to serve as a duplicate sample. A total of 17 samples were collected for particle size analysis using the SSPSS apparatus.

The soil samples were sieved into six size-fractions with physical diameters greater than $600 \mu \mathrm{m}, 300$ to $600 \mu \mathrm{m}, 150$ to $300 \mu \mathrm{m}, 75$ to $150 \mu \mathrm{m}, 38$ to $75 \mu \mathrm{m}$, and less than $38 \mu \mathrm{m}$. The $38-\mu \mathrm{m}$ fraction was further separated by aerodynamic sizing into five size-fractions with aerodynamic diameters less than $1 \mu \mathrm{m}$, less than $2.5 \mu \mathrm{m}$, less than $5 \mu \mathrm{m}$, less than $10 \mu \mathrm{m}$, and less than $15 \mu \mathrm{m}$. No additional analysis was conducted on the $38-\mu \mathrm{m}$ to $15-\mu \mathrm{m}$ particle-size range. Quanterra Environmental Services, Richland Laboratory, analyzed the aerodynamically separated particle samples for plutonium, americium, and uranium using alpha spectroscopy. UNLV's Department of Health Physics analyzed the sieved size-fractions for americium using gamma spectroscopy. Quality assurance/quality control included steps during sieving operations to minimize loss of material during shaking and during transfer from the sieves for weighing and analysis. For filter SSPSS operations and filter analysis quality assurance/quality control steps including simultaneous sampling of two, less than 5- $\mu \mathrm{m}$ size-fraction samples; random weighing of a control set of filters and with other calibration weights; leak tests and flow rate checks of the SSPSS equipment during operation, and a 5 to 10 minute "settling" period before filters were removed to help ensure that no particles remained in suspension.

Aerodynamically separated particles from 15 soil samples (five soil samples at each location) were analyzed by alpha spectroscopy for ${ }^{239+240} \mathrm{Pu}$ and ${ }^{241} \mathrm{Am}$. The analyzed activities for ${ }^{239+240} \mathrm{Pu}$ ranged from 54 to $1,390 \mathrm{pCi} / \mathrm{g}$ for location one, from 450 to $9,000 \mathrm{pCi} / \mathrm{g}$ for location two, and from 83 to $1,600 \mathrm{pCi} / \mathrm{g}$ for location three. The analyzed activities for ${ }^{241} \mathrm{Am}$ ranged from 10 to $254 \mathrm{pCi} / \mathrm{g}$ for location one, from 14 to $1,490 \mathrm{pCi} / \mathrm{g}$ for location two, and from 14 to $220 \mathrm{pCi} / \mathrm{g}$ for location three. Several soil samples had more activity in the smaller size-fractions than in the larger ones, which indicates that radioactive particles were uniformly distributed in the SSPSS suspension chamber during particle separation. The filters were also analyzed for uranium by alpha 
spectroscopy. Uranium was found on four samples at low levels: 1.12 to $3.72 \mathrm{pCi} / \mathrm{g}$ (0.06 to $0.11 \mathrm{pCi}$ total activity).

For the aerodynamically separated samples, the average ratio of ${ }^{239+240} \mathrm{Pu}$ to ${ }^{241} \mathrm{Am}$ for all size-fractions was 7.1 with a standard deviation of 10.8 , a range of 0.8 to 78.5 . The averages for the different size-ranges had slight but not significant differences. At the $95 \%$ confidence limit, the range was 4.6 to 9.6. The ratio of 7.1 is lower than the ratio of ${ }^{239+240} \mathrm{Pu}$ to ${ }^{241} \mathrm{Am}$ found for soil samples at safety test sites on the Tonopah Test Range, consistent with previous work at Project 57.

The activities in the size-intervals for aerodynamic diameters $<2.5 \mu \mathrm{m}$, from 2.5 to $5 \mu \mathrm{m}$, from 5 to $10 \mu \mathrm{m}$, and from 10 to $15 \mu \mathrm{m}$ were computed from the mass and activities on filter samples. The mean activity of ${ }^{239+240} \mathrm{Pu}$ on the aerodynamically separated samples increased as the particle size increased: $377 \mathrm{pCi} / \mathrm{g}$ for the $<2.5 \mu \mathrm{m}$ interval, $592 \mathrm{pCi} / \mathrm{g}$ for the 2.5 to $5 \mu \mathrm{m}$ interval, $1,211 \mathrm{pCi} / \mathrm{g}$ for 5 to $10 \mu \mathrm{m}$ interval, and $1,922 \mathrm{pCi} / \mathrm{g}$ for the 10 to $15 \mu \mathrm{m}$ interval. Paired t-tests show statistically significant increases in ${ }^{239+240} \mathrm{Pu}$ activity between the $<2.5 \mu \mathrm{m}$ and $2.5-5 \mu \mathrm{m}$ intervals (at the 3.4\% level) and the 2.5-5 $\mu \mathrm{m}$ and 5-10 $\mu \mathrm{m}$ intervals (at the $1.3 \%$ level). The increase between the 5-10 $\mu \mathrm{m}$ and 10-15 $\mu \mathrm{m}$ interval had a significance level of $12.5 \%$ and would not be considered statistically significant.

The means of the ${ }^{241} \mathrm{Am}$ activities for the aerodynamically separated samples in the $<2.5 \mu \mathrm{m}$, from 2.5 to $5 \mu \mathrm{m}$, from 5 to $10 \mu \mathrm{m}$, and from 10 to $15 \mu \mathrm{m}$ size-intervals were also determined. Although the ${ }^{241} \mathrm{Am}$ activities increased as the particle size increased, no increase was statistically significant.

The relation among ${ }^{241} \mathrm{Am}$ activities of the sieved samples at the three sampling locations and the individual samples was similar to that of the aerodynamically separated samples. The highest activities were found at location two (9 to $2,632 \mathrm{pCi} / \mathrm{g}$ ); the activity at location three (4 to $1,280 \mathrm{pCi} / \mathrm{g}$ ) slightly exceeded that at location one (1 to $597 \mathrm{pCi} / \mathrm{g})$. The individual soil samples with the highest alpha activities also had the highest gamma activities; the individual soil samples with the lowest alpha activities also had the lowest gamma activities. A few soil samples had one or more size-intervals with much higher activity than is found in other size-intervals for that sample, which is indicative of the inhomogeneity of the mixture of radionuclides in the sample. However, in general, the results suggest that the plutonium and americium were similarly distributed among different soil particle sizes at the sampling sites.

The mean activity of the sieved samples decreased as the particle size increased for all but the 150 to $300 \mu \mathrm{m}$ size-interval. Except for one soil sample with a high ${ }^{241} \mathrm{Am}$ activity in the 150 to $300 \mu \mathrm{m}$ interval, mean activities decreased with increasing particle size for all sizes. Paired t-Tests confirm that the decreases in the means with increasing particle size were highly statistically significant for the $<38 \mu \mathrm{m}$ to $38-75 \mu \mathrm{m}$ interval (at the $0.0 \%$ level), for the $75-15 \mu \mathrm{m}$ to $150-300 \mu \mathrm{m}$ interval (at the $0.8 \%$ level) and for the $150-300 \mu \mathrm{m}$ to $300-600 \mu \mathrm{m}$ interval (at the $0.6 \%$ level). The decrease for the $300-600 \mu \mathrm{m}$ to $>600 \mu \mathrm{m}$ interval was slightly less significant but still at the $3.5 \%$ level. The decrease in the mean activity between the 38-75 $\mu \mathrm{m}$ to $75-150 \mu \mathrm{m}$ interval had a significance level of $7.2 \%$, only slightly statistically significant.

The activities of ${ }^{241} \mathrm{Am}$ in the sieved samples, particularly in the small size-intervals, are higher (range of 8.4 to $2,630 \mathrm{pCi} / \mathrm{g}$ ) than might be expected given the activities of ${ }^{241} \mathrm{Am}$ and 
${ }^{239+240} \mathrm{Pu}$ in the aerodynamically separated samples. If the same ratio of about 5 for plutonium to americium as for the aerodynamically separated size-fractions holds for the sieved samples, the plutonium activity in the $<38 \mu \mathrm{m}$ size-range would be from 800 to $13,000 \mathrm{pCi} / \mathrm{g}$. The results of the gamma counting of ${ }^{241} \mathrm{Am}$ and subsequent calculations have been checked and determined to be correct to within the uncertainties of the measurement. A large amount of plutonium associated with particles having aerodynamic diameters greater than $15 \mu \mathrm{m}$ (a diameter of about $3 \mu \mathrm{m}$ for a plutonium particle or $5 \mu \mathrm{m}$ for a plutonium oxide particle) and physical sizes less than $38 \mu \mathrm{m}$ could result in the high activities in this size range.

The total amount of ${ }^{241} \mathrm{Am}$ in each sieved sample cannot be determined, because the sieved fractions were not weighed when the separations were done. The sieved fractions were not originally intended to be analyzed. The sieved fractions were analyzed only after a gross gamma survey meter indicated relatively high activities in some of the sieved fractions. Previous work at the site by Papelis et al. (1996) indicated slightly more than $50 \%$ of the Pu activity is associated with particles less than $38 \mu \mathrm{m}$. However, variability between samples was high. In the future, for any work with the SSPSS, the total weight of the soil sample, the weight of the part that is sieved, and the weights of each sieved size-fraction should be determined. The principal value of this would be for a better understanding of activity as a function of soil mass distribution, both in the inhalable and larger soil particle-size ranges. 


\section{CONTENTS}

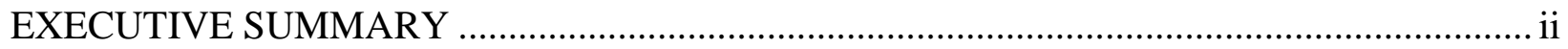

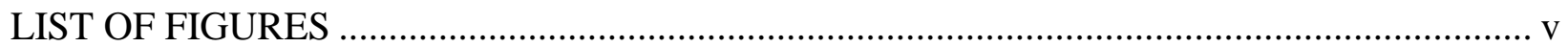

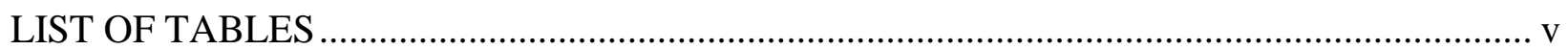

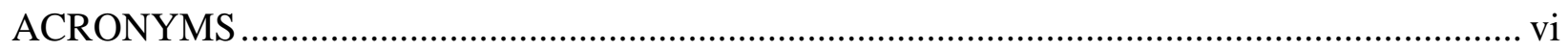

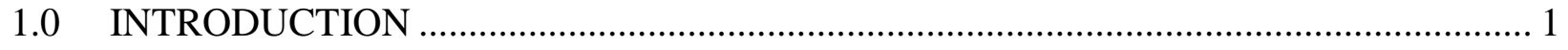

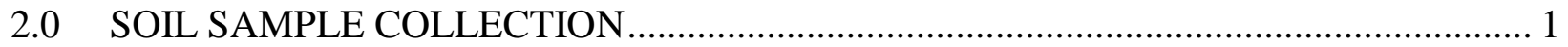

3.0 SSPSS OPERATIONS AND ANALYTICAL RESULTS .......................................... 4

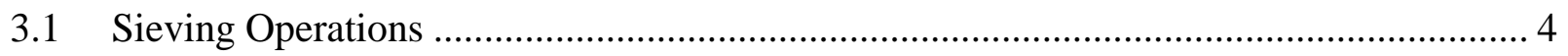

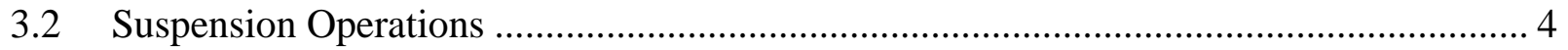

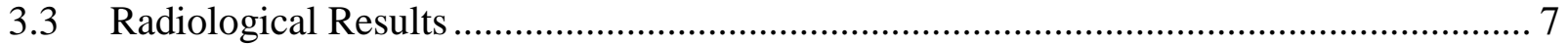

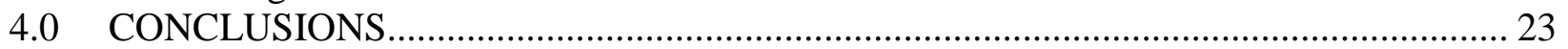

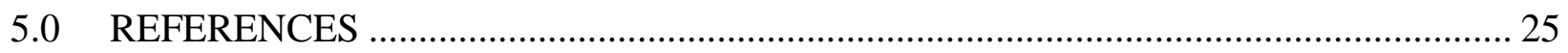

\section{LIST OF FIGURES}

1. Location of soil samples at Project 57 ......................................................................... 1

2. Operations associated with the SSPSS and analytical operations. ....................................... 5

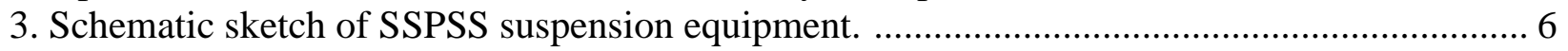

\section{LIST OF TABLES}

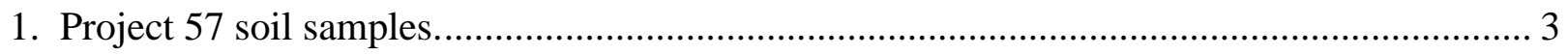

2. Mass on aerodynamically separated size-fractions - location one . ................................ 8

3. Mass on aerodynamically separated size-fractions - location two.................................. 9

4. Mass on aerodynamically separated size-fractions - location three................................. 10

5. Radioactivity on aerodynamically separated size-fractions - location one........................ 12

6. Radioactivity on aerodynamically separated size-fractions - location two........................ 13

7. Radioactivity on aerodynamically separated size-fractions - location three...................... 14

8. Ratio of ${ }^{239+240} \mathrm{Pu}$ to ${ }^{241} \mathrm{Am}$ activity for aerodynamic size-fractions.................................. 15

9. Activity of ${ }^{239+240} \mathrm{Pu}$ for aerodynamic size-fractions. ............................................... 17

10. Activity of ${ }^{241} \mathrm{Am}$ for aerodynamic size-fractions. ....................................................... 18

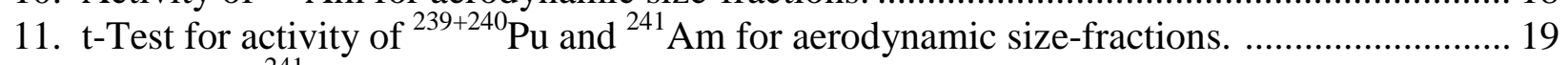

12. Activity of ${ }^{241} \mathrm{Am}$ for sieved size-fractions................................................................. 21

13. $\mathrm{t}$-Test for activity of ${ }^{241} \mathrm{Am}$ for sieved size-fractions................................................... 22 


\section{ACRONYMS}

$\begin{array}{ll}\text { AD } & \begin{array}{l}\text { aerodynamic diameters } \\ \text { americium }\end{array} \\ \text { Am } & \text { Division of Atmospheric Science } \\ \text { DAS } & \begin{array}{l}\text { Desert Research Institute } \\ \text { high-efficiency particle arresting } \\ \text { DRI }\end{array} \\ \text { HEPA } & \text { Harry Reid Center } \\ \text { HRC } & \text { physical diameters } \\ \text { PD } & \text { plutonium } \\ \text { Pu } & \text { Quanterra Environ-Services } \\ \text { QES } & \text { standard operating procedure } \\ \text { SOP } & \text { suspended soil particle sizing system } \\ \text { SSPSS } & \text { Tonopah Test Range } \\ \text { TTR } & \text { University of Nevada, Las Vegas }\end{array}$




\subsection{INTRODUCTION}

As part of the preliminary site characterization conducted for Project 57, soil samples were collected for separation into several size-fractions using the Suspended Soil Particle Sizing System (SSPSS), designed and fabricated by the Division of Atmospheric Sciences (DAS) of the Desert Research Institute (DRI) (Bowen et al., 1998; Chow et al., 1994). Soil samples were collected specifically for separation by the SSPSS at three general locations in the deposited Project 57 plume, the projected radioactivity of which ranged from 100 to $600 \mathrm{pCi} / \mathrm{g}$. The primary purpose in focusing on samples with this level of activity is that it would represent anticipated residual soil contamination levels at the site after corrective actions are completed. Consequently, the results of the SSPSS analysis can contribute to dose calculation and corrective action-level determinations for future land-use scenarios at the site.

Project 57 was a safety test conducted on the Nellis Air Force Range. The purpose of the test was to evaluate the dispersal of plutonium resulting from a chemical explosion of a simulated nuclear device. IT Corporation collected soil samples for the SSPSS analysis as part of preliminary characterization work at the site. The SSPSS operations, consisting of particle separation by sieving and aerodynamic sizing, were performed by personnel of the Harry Reid Center for Environmental Studies (HRC) at the University of Nevada, Las Vegas (UNLV). Sieving was done in the Radiation Protection Laboratory at UNLV. The aerodynamic particle separation was done at the HRC. Quanterra Environmental Services (QES), Richland Laboratory, analyzed the aerodynamically separated particle samples for isotopes of plutonium, americium, and uranium. UNLV's Department of Health Physics analyzed the sieved size-fractions for americium using gamma spectroscopy.

\subsection{SOIL SAMPLE COLLECTION}

During collection of soil samples for other preliminary site characterization, IT Corporation collected soil samples specifically for the separation of soil particles by the SSPSS. At each sample site, surface vegetation and debris were removed and soil was collected to a depth of approximately $8 \mathrm{~cm}$, placed in a 2-liter container, and marked with a sample identification number. A total of 17 samples were collected at three general locations relative to the estimated plume area shown in Figure 1. The projected activity of the areas of collection was in the range of 100 to $600 \mathrm{pCi} / \mathrm{g}$, the anticipated residual contaminant level range that will remain at the site after corrective action. Higher activity soils were also not considered because of restrictions on the amount of radioactive material that UNLV was licensed to have in its possession. Five soil samples with these activities could be transferred to UNLV at one time for separation. The sample locations and sample identification numbers are listed in Table 1. Two of the samples, PR57-058 and PR57-057, were collected at the same location as samples PR57-035 and PR57-040, respectively, to serve as duplicate samples. 


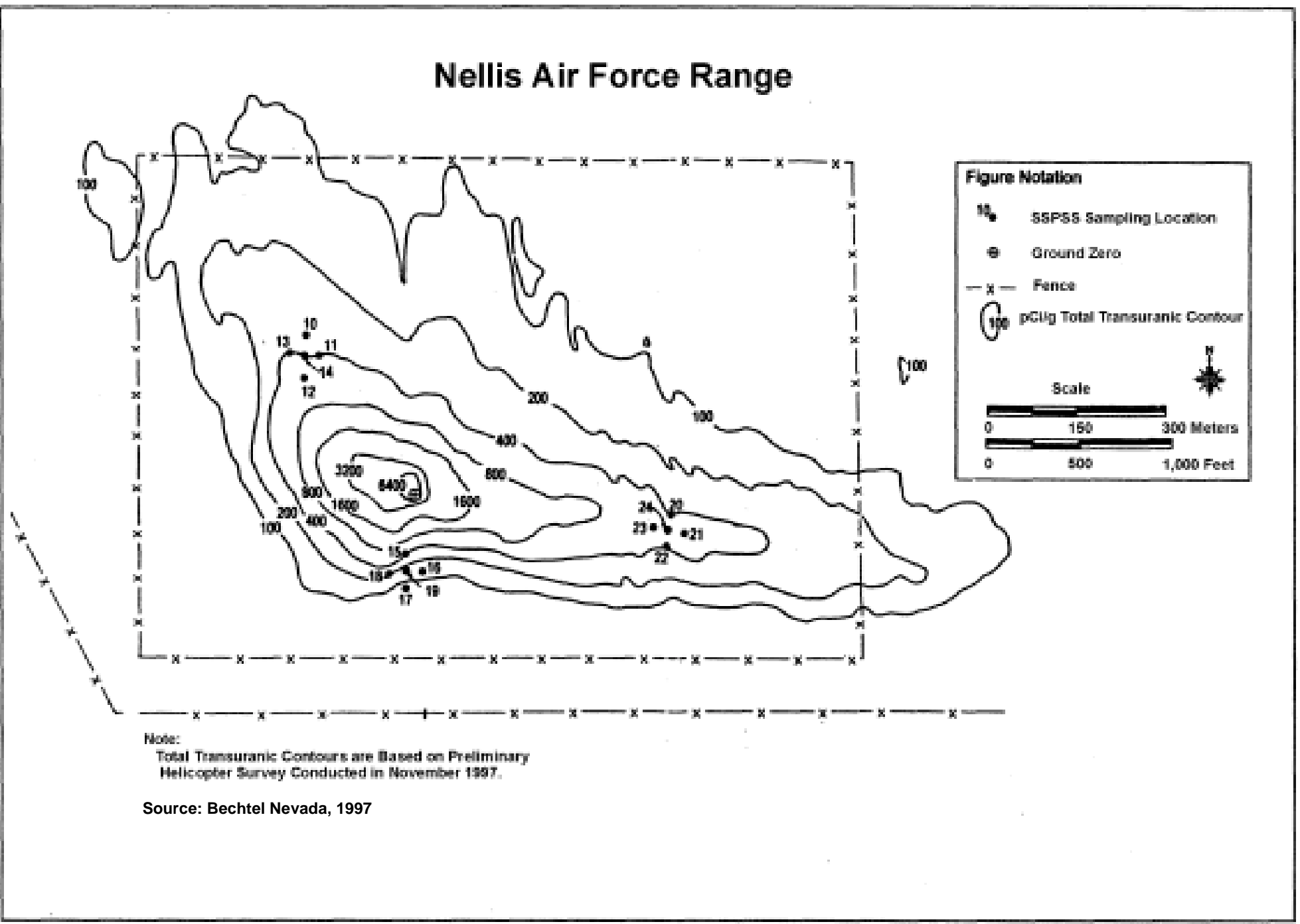

Figure 1. Location of soil samples at Project 57. 
Table 1. Project 57 soil samples.

\begin{tabular}{|c|c|c|c|c|}
\hline \multirow[b]{2}{*}{$\begin{array}{l}\text { Sample } \\
\text { Location }\end{array}$} & \multirow[b]{2}{*}{$\begin{array}{l}\text { Sample } \\
\text { ID }\end{array}$} & \multicolumn{2}{|c|}{ From Ground Zero } & \multirow[b]{2}{*}{ Comment } \\
\hline & & $\begin{array}{c}\text { Bearing } \\
\text { Degrees } \\
\text { Relative to } \\
\text { North }\end{array}$ & $\begin{array}{l}\text { Distance } \\
\text { (m) }\end{array}$ & \\
\hline \multicolumn{5}{|l|}{ Location One } \\
\hline 10 & PR57-026 & 327 & 324 & \\
\hline 11 & PR57-027 & 327 & 285 & \\
\hline 12 & PR57-028 & 318 & 270 & \\
\hline 13 & PR57-029 & 319 & 318 & \\
\hline 14 & PR57-030 & 320 & 297 & \\
\hline \multicolumn{5}{|l|}{ Location Two } \\
\hline 15 & PR57-031 & 187 & 99 & \\
\hline 16 & PR57-032 & 174 & 129 & Not Separated \\
\hline 17 & PR57-033 & 185 & 159 & \\
\hline 18 & PR57-034 & 198 & 141 & \\
\hline 19 & PR57-035 & 186 & 129 & \\
\hline 19 & PR57-058 & 186 & 129 & Duplicate \\
\hline \multicolumn{5}{|c|}{ Location Three } \\
\hline 20 & PR57-036 & 94 & 438 & \\
\hline 21 & PR57-037 & 98 & 465 & \\
\hline 22 & PR57-038 & 102 & 438 & Not Separated \\
\hline 23 & PR57-039 & 98 & 411 & \\
\hline 24 & PR57-040 & 98 & 438 & \\
\hline 24 & PR57-057 & 98 & 438 & Duplicate \\
\hline
\end{tabular}




\subsection{SSPSS OPERATIONS AND ANALYTICAL RESULTS}

UNLV received soil samples from IT Corporation in three separate shipments, one for each sampling location. Each set consisted of the five or six samples indicated in Table 1. The soil samples were dried and then sieved into six size-fractions, the smallest of which had particles with physical diameters less than $38 \mu \mathrm{m}$. The $<38 \mu \mathrm{m}$ fraction was further separated into five sizefractions with aerodynamic diameters $<1,<2.5,<5,<10$, and $<15 \mu \mathrm{m}$, respectively. The samples were received, transported, handled, and stored in accordance with the Radiation Safety Standard Operating Procedure (SOP) for the Soil Analyses Laboratory and SSPSS. Training of personnel was performed in accordance with this SOP. Figure 2 contains a flow diagram of the operations associated with the SSPSS and analytical operations that are described in this section. In the following discussion, particle size-fractions are determined by the method of separation: physical diameters (PD) for the sieving process and aerodynamic diameters (AD) referenced to a spherical particle with a density of $1 \mathrm{~g} / \mathrm{cm}^{3}$.

\section{1 $\quad$ Sieving Operations}

Sieving operations were performed in a large laboratory hood in UNLV's Radiation Protection Laboratory. The hood was equipped with a high-efficiency particle arresting (HEPA) filter on the exhaust to prevent possible release of contaminated dust to the atmosphere. Prior to sieving, the bulk soil samples were dried at $110^{\circ} \mathrm{C}$ for several hours. For each soil sample, approximately half a kilogram of soil was placed in the top sieve of the stack. The sieve stack was shaken for 20 minutes to separate the soil into six size-fractions with physical diameters greater than $600 \mu \mathrm{m}, 300$ to $600 \mu \mathrm{m}, 150$ to $300 \mu \mathrm{m}, 75$ to $150 \mu \mathrm{m}, 38$ to $75 \mu \mathrm{m}$, and less than $38 \mu \mathrm{m}$. The five larger size-fractions were placed in labeled bags for possible further analysis. The $<38 \mu \mathrm{m}$ sizefraction was placed in a 50-ml container and taken to the suspension area for aerodynamic separation to smaller size-fractions. The shaker stakes were locked together during the sieving operation to minimize the potential for fine particles to escape. In addition, the stake was observed during the entire 6 to 15 minute shaking operation. No escape of fines was observed.

\subsection{Suspension Operations}

Suspension operations were performed in a small laboratory room in the HRC. Inside the laboratory, a secondary containment structure was constructed of PVC tubing and polyethylene sheeting to contain soil particles that might be released during operations of the apparatus. The most likely time for a release of particles to the air was during the cleanup after the separation process. A vacuum cleaner with a HEPA filter was used to remove soil that fell out in the suspension chamber. An air-cleaning device with HEPA filter was installed in the secondary containment area to collect dust released during cleanup operations. A HEPA filter was also installed on the exhaust fan outlet from the room to prevent release of contaminated particles to the atmosphere.

For each soil sample, a portion of the final sieved product ( $<38 \mu \mathrm{m}$ fraction) was separated aerodynamically into five size-fractions with aerodynamic diameters $<1 \mu \mathrm{m},<2.5 \mu \mathrm{m},<5 \mu \mathrm{m}$, $<10 \mu \mathrm{m}$, and $<15 \mu \mathrm{m}$, respectively. The SSPSS separation apparatus is shown schematically in Figure 3. The <38 m sample was introduced to the suspension chamber through the suspension flask. The suspended particles separated into different size-fractions by the impactors specific to 


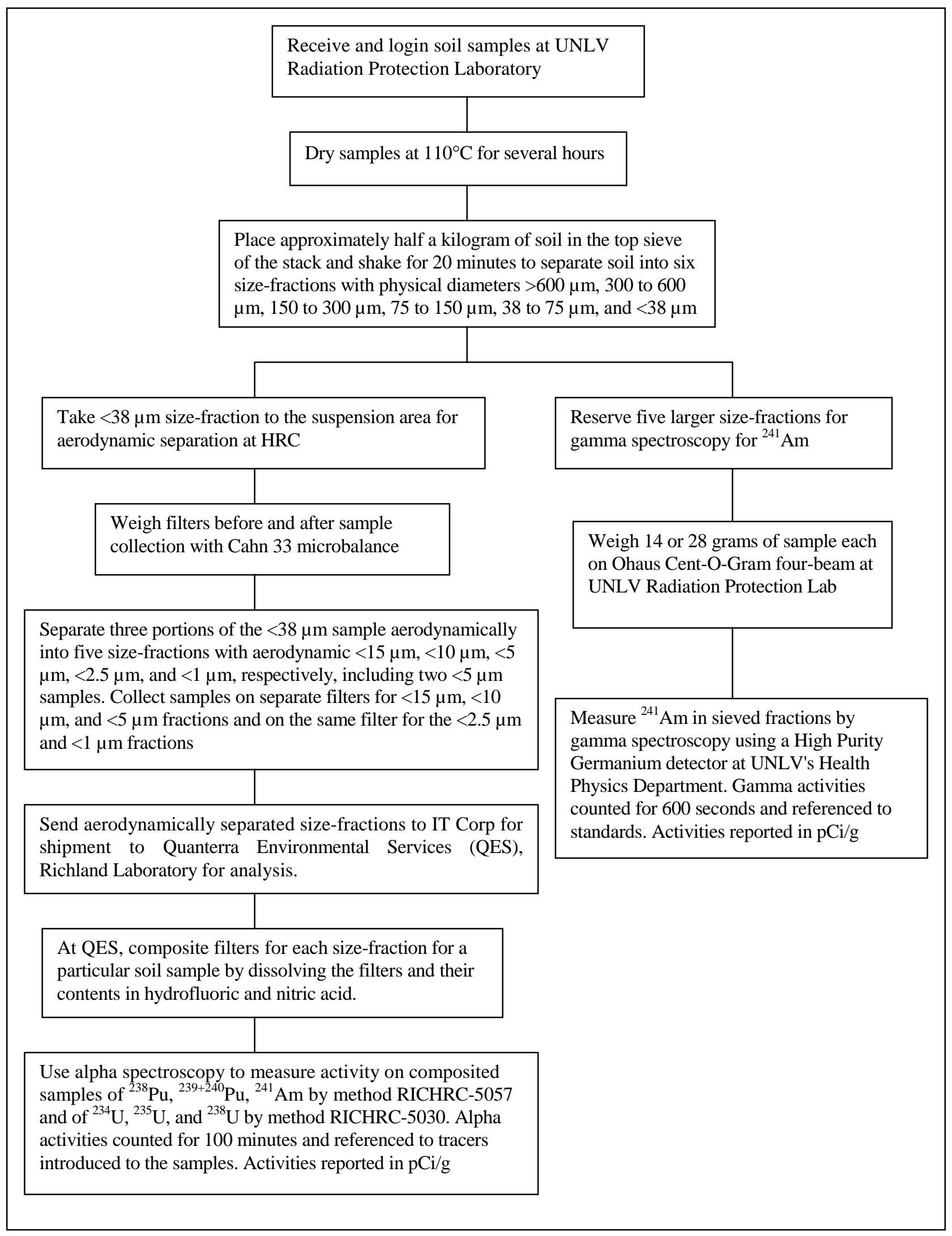

Figure 2. Operations associated with the SSPSS and analytical operations. 


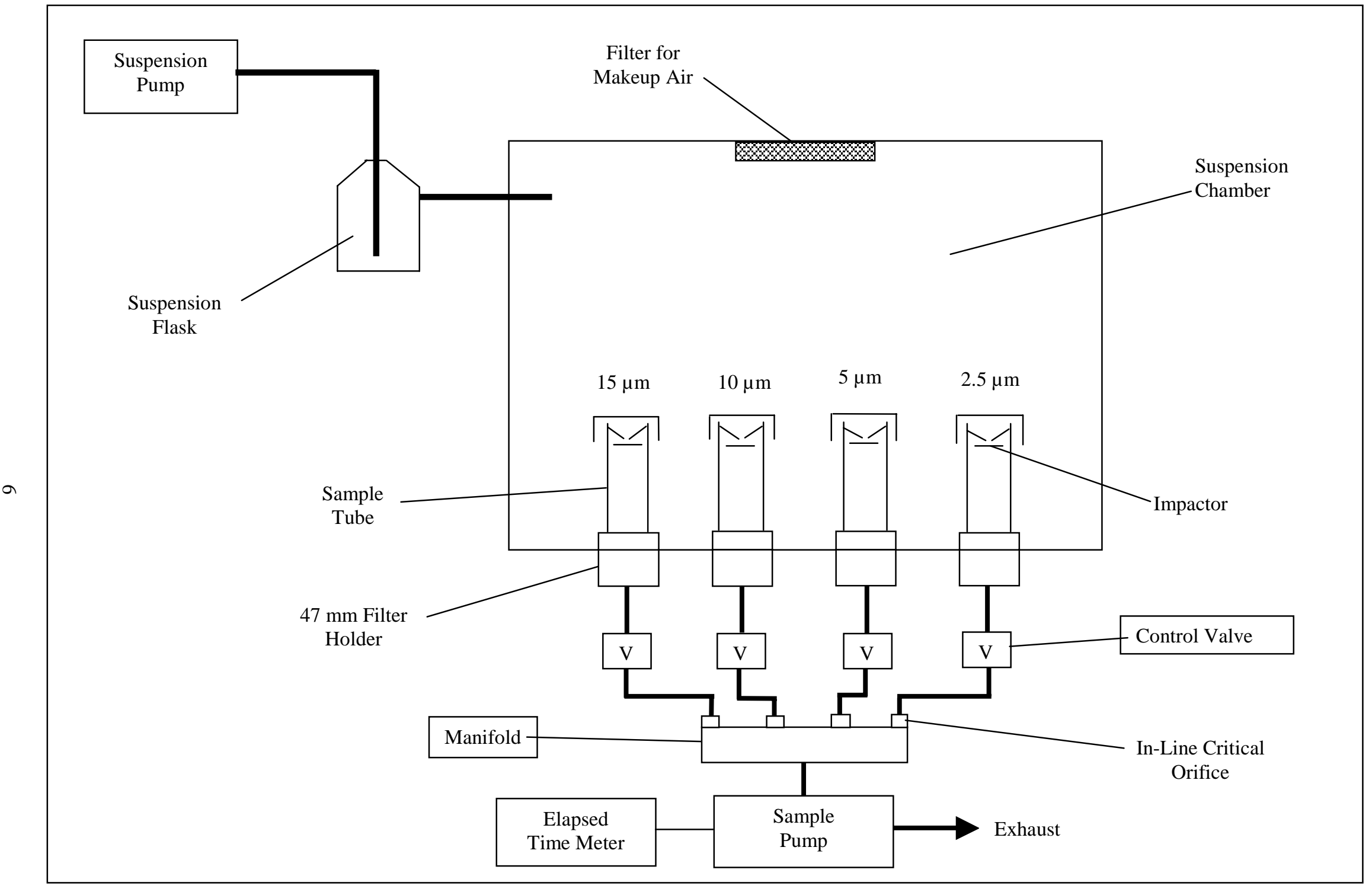

Figure 3. Schematic sketch of SSPSS suspension equipment. 
each size and were collected on filters for subsequent analysis. A second sample in the $<5 \mu \mathrm{m}$ size-fraction was also collected as a check of the homogeneity of the suspended particles. To collect the amount of mass required for the analysis of plutonium, three suspensions were performed for each soil sample. The $<5 \mu \mathrm{m},<10 \mu \mathrm{m}$ and $<15 \mu \mathrm{m}$ size-fractions were collected on separate filters for each suspension, so as not to overload the filters and impaction plates. For all but two soil samples, the $<1 \mu \mathrm{m}$ and $<2.5 \mu \mathrm{m}$ size-fractions were collected on single filters, because of the small amount of mass collected for those sizes. The filters were weighed before and after the soil collection with a Cahn Model 33 microbalance to determine the amount of suspended soil collected. A control set of filters and calibration weights were randomly reweighed as a quality control procedure. This was done in place of making multiple measurements of the filters to minimize handling of the filters during which material could be lost. In addition, particularly for the benefit of the finest filter fractions, a 5 to 10 minute "settling" period was used after operation of the SSPSS apparatus before the filters were removed to help ensure that no fine particles remained in suspension. In addition, leak tests and flow rate checks, in accordance with the DRI SOP, were performed during the SSPSS operation.

The $<1 \mu \mathrm{m}$ samples for the Project 57 samples contained higher than expected masses. The average ratio of mass on the $<1 \mu \mathrm{m}$ samples to mass on the $<2.5 \mu \mathrm{m}$ samples was $0.66 \pm 0.08$; i.e., two thirds of the $<2.5 \mu \mathrm{m}$ size-fraction would have consisted of particles smaller than $<1 \mu \mathrm{m}$. Other measurements have found that airborne particles originating from soil have less than $10 \%$ of the total mass in the $<1 \mu \mathrm{m}$ and smaller size-fraction (Friedlander, 1977; Whitby, 1978). Airborne particles that originate as suspended soil particles typically have a lognormal mass distribution with a maximum near $9 \mu \mathrm{m}$ and geometric standard deviation of about $5 \mu \mathrm{m}$. The mass in the $<1 \mu \mathrm{m}$ size-fraction for such a distribution would be about $7 \%$ of the mass in the $<2.5 \mu \mathrm{m}$ size-fraction, or much less than the $66 \%$ found for the current measurements. The processes used in the SSPSS to separate particles, while not exactly the same as those that would generate airborne particles by natural processes, would not have modified the soil sample so much as to result in the measured abundance of mass in the $<1 \mu \mathrm{m}$ size-range. As a consequence, the results of $<1 \mu \mathrm{m}$ samples were combined with the $<2.5 \mu \mathrm{m}$ fraction for analysis. The $<1 \mu \mathrm{m}$ samples will not be considered further during this report.

The aerodynamically separated samples are listed in Tables 2 through 4 . Also included are filter numbers and individual masses and the composite sets and total mass of all the filters for a particular size-fraction for each sample. The samples labeled $5 \mathrm{~A}$ are those for the second $<5 \mu \mathrm{m}$ size-fraction.

\subsection{Radiological Results}

Both the sieved fractions and the aerodynamically separated fractions were analyzed for radionuclides. The following section describes the two types of analyses performed.

\section{Aerodynamically Separated Fractions - Alpha Spectroscopy}

The aerodynamically separated samples were analyzed for plutonium $\left({ }^{239+240} \mathrm{Pu}\right.$ and $\left.{ }^{238} \mathrm{Pu}\right)$, americium $\left({ }^{241} \mathrm{Am}\right)$, and uranium $\left({ }^{234} \mathrm{U},{ }^{235} \mathrm{U}\right.$, and $\left.{ }^{238} \mathrm{U}\right)$ by QES, Richland Laboratory. After aerodynamic separation, and sample collection and weighing at UNLV, the sample filters were sent to IT Corporation for shipment to QES. All soil samples had three filters for each size-fraction at 5 $\mu \mathrm{m}$ and larger. A few of the smaller size-fractions also had multiple filters but most samples consisted of a single filter. At QES, the filters for each size-fraction for a particular soil sample were 
Table 2. Mass on aerodynamically separated size-fractions - location one.

\begin{tabular}{|c|c|c|c|c|c|c|c|c|}
\hline \multirow{2}{*}{$\begin{array}{l}\text { Soil Sample } \\
\text { ID }\end{array}$} & \multirow{2}{*}{$\begin{array}{c}\text { Size- } \\
\text { Fraction, } \\
\text { Aerodynamic } \\
\text { Diameter, } \\
\mu \mathrm{m}\end{array}$} & \multicolumn{2}{|c|}{ Filter 1} & \multicolumn{2}{|c|}{ Filter 2} & \multicolumn{2}{|c|}{ Filter 3} & \multirow{2}{*}{$\begin{array}{c}\text { Sum Mas } \\
\text { Mg }\end{array}$} \\
\hline & & ID & Mass, mg & ID & Mass, mg & ID & Mass, mg & \\
\hline \multirow[t]{6}{*}{ PR57-026 } & $<1$ & PR57001 & 3.686 & - & - & - & - & 3.686 \\
\hline & $<2.5$ & PR57002 & 2.060 & PR57007 & 1.461 & PR57012 & 3.120 & 6.641 \\
\hline & $<5$ & PR57003 & 11.392 & PR57008 & 8.364 & PR57013 & 2.803 & 22.559 \\
\hline & $<5 \mathrm{~A}$ & PR57004 & 12.645 & PR57009 & 8.694 & PR57014 & 15.039 & 36.378 \\
\hline & $<10$ & PR57005 & 21.204 & PR57010 & 14.938 & PR57015 & 33.136 & 69.278 \\
\hline & $<15$ & PR57006 & 25.991 & PR57011 & 17.497 & PR57016 & 26.386 & 69.874 \\
\hline \multirow[t]{6}{*}{ PR57-027 } & $<1$ & PR57034 & 2.160 & - & - & - & - & 2.160 \\
\hline & $<2.5$ & PR57035 & 3.827 & - & - & - & - & 3.827 \\
\hline & $<5$ & PR57036 & 6.812 & PR57040 & 6.435 & PR57044 & 5.507 & 18.754 \\
\hline & $<5 \mathrm{~A}$ & PR57037 & 7.680 & PR57041 & 7.773 & PR57045 & 7.048 & 22.501 \\
\hline & $<10$ & PR57038 & 15.941 & PR57042 & 14.956 & PR57046 & 8.974 & 39.871 \\
\hline & $<15$ & PR57039 & 22.577 & PR57043 & 19.607 & PR57047 & 15.601 & 57.785 \\
\hline \multirow{6}{*}{ PR57-028 } & $<1$ & PR57048 & 5.436 & - & - & - & - & 5.436 \\
\hline & $<2.5$ & PR57049 & 9.881 & - & - & - & - & 9.881 \\
\hline & $<5$ & PR57050 & 17.617 & PR57054 & 12.938 & PR57058 & 10.476 & 41.031 \\
\hline & $<5 \mathrm{~A}$ & PR57051 & 18.584 & PR57055 & 12.296 & PR57059 & 10.880 & 41.760 \\
\hline & $<10$ & PR57052 & 33.033 & PR57056 & 26.983 & PR57060 & 23.669 & 83.685 \\
\hline & $<15$ & PR57053 & 43.453 & PR57057 & 31.364 & PR57061 & 19.889 & 94.706 \\
\hline \multirow[t]{6}{*}{ PR57-029 } & $<1$ & PR57018 & 3.209 & PR57024 & 2.115 & - & - & 5.324 \\
\hline & $<2.5$ & PR57019 & 1.552 & PR57025 & 8.092 & - & - & 9.644 \\
\hline & $<5$ & PR57020 & 8.370 & PR57026 & 9.329 & PR57030 & 11.055 & 28.754 \\
\hline & $<5 \mathrm{~A}$ & PR57021 & 9.786 & PR57027 & 16.726 & PR57031 & 12.515 & 39.027 \\
\hline & $<10$ & PR57022 & 19.410 & PR57028 & 23.914 & PR57032 & 21.310 & 64.634 \\
\hline & $<15$ & PR57023 & 14.486 & PR57029 & 2.795 & PR57033 & 30.244 & 47.525 \\
\hline \multirow[t]{6}{*}{ PR57-030 } & $<1$ & PR57062 & 4.153 & - & - & - & - & 4.153 \\
\hline & $<2.5$ & PR57063 & 5.188 & - & - & - & - & 5.188 \\
\hline & $<5$ & PR57064 & 8.183 & PR57068 & 9.641 & PR57072 & 6.995 & 24.819 \\
\hline & $<5 \mathrm{~A}$ & PR57065 & 9.769 & PR57069 & 11.370 & PR57073 & 10.732 & 31.871 \\
\hline & $<10$ & PR57066 & 15.375 & PR57070 & 21.440 & PR57074 & 16.830 & 53.645 \\
\hline & $<15$ & PR57067 & 19.128 & PR57071 & 24.752 & PR57075 & 24.440 & 68.320 \\
\hline
\end{tabular}


Table 3. Mass on aerodynamically separated size-fractions - location two.

\begin{tabular}{|c|c|c|c|c|c|c|c|c|}
\hline \multirow{2}{*}{$\begin{array}{l}\text { Soil Sample } \\
\text { ID }\end{array}$} & \multirow{2}{*}{$\begin{array}{c}\text { Size- } \\
\text { Fraction, } \\
\text { Aerodynamic } \\
\text { Diameter, } \\
\mu \mathrm{m}\end{array}$} & \multicolumn{2}{|c|}{ Filter 1} & \multicolumn{2}{|c|}{ Filter 2} & \multicolumn{2}{|c|}{ Filter 3} & \multirow{2}{*}{$\begin{array}{c}\text { Sum Mass } \\
\mathrm{Mg}\end{array}$} \\
\hline & & ID & Mass, mg & ID & Mass, mg & ID & Mass, mg & \\
\hline \multirow[t]{6}{*}{ PR57-031 } & $<1$ & PR57076 & 4.567 & - & - & - & - & 4.567 \\
\hline & $<2.5$ & PR57077 & 7.205 & - & - & - & - & 7.205 \\
\hline & $<5$ & PR57078 & 9.782 & PR57082 & 6.746 & PR57086 & 17.937 & 34.465 \\
\hline & $<5 \mathrm{~A}$ & PR57079 & 9.683 & PR57083 & 7.957 & PR57087 & 18.167 & 35.807 \\
\hline & $<10$ & PR57080 & 22.430 & PR57084 & 12.280 & PR57088 & 36.114 & 70.824 \\
\hline & $<15$ & PR57081 & 27.215 & PR57085 & 19.002 & PR57089 & 43.109 & 89.326 \\
\hline \multirow[t]{6}{*}{ PR57-033 } & $<1$ & PR57090 & 7.508 & - & - & - & - & 7.508 \\
\hline & $<2.5$ & PR57091 & 9.886 & - & - & - & - & 9.886 \\
\hline & $<5$ & PR57092 & 13.538 & PR57096 & 10.908 & PR57100 & 12.597 & 37.043 \\
\hline & $<5 \mathrm{~A}$ & PR57093 & 13.914 & PR57097 & 12.950 & PR57101 & 13.827 & 40.691 \\
\hline & $<10$ & PR57094 & 29.579 & PR57098 & 23.644 & PR57102 & 24.870 & 78.093 \\
\hline & $<15$ & PR57095 & 40.264 & PR57099 & 33.422 & PR57103 & 33.205 & 106.891 \\
\hline \multirow[t]{6}{*}{ PR57-034 } & $<1$ & PR57104 & 5.432 & - & - & - & - & 5.432 \\
\hline & $<2.5$ & PR57105 & 8.262 & - & - & - & - & 8.262 \\
\hline & $<5$ & PR57106 & 9.053 & PR57110 & 13.795 & PR57114 & 13.193 & 36.041 \\
\hline & $<5 \mathrm{~A}$ & PR57107 & 9.227 & PR57111 & 15.509 & PR57115 & 15.427 & 40.163 \\
\hline & $<10$ & PR57108 & 20.031 & PR57112 & 31.901 & PR57116 & 41.339 & 93.271 \\
\hline & $<15$ & PR57109 & 27.350 & PR57113 & 43.719 & PR57117 & 28.551 & 99.620 \\
\hline \multirow[t]{6}{*}{ PR57-035 } & $<1$ & PR57118 & 7.966 & - & - & - & - & 7.966 \\
\hline & $<2.5$ & PR57119 & 11.256 & - & - & - & - & 11.256 \\
\hline & $<5$ & PR57120 & 20.330 & PR57124 & 12.798 & PR57128 & 15.874 & 49.002 \\
\hline & $<5 \mathrm{~A}$ & PR57121 & 21.784 & PR57125 & 13.449 & PR57129 & 16.977 & 52.210 \\
\hline & $<10$ & PR57122 & 38.859 & PR57126 & 25.984 & PR57130 & 33.404 & 98.247 \\
\hline & $<15$ & PR57123 & 53.334 & PR57127 & 37.796 & PR57131 & 42.263 & 133.393 \\
\hline \multirow[t]{6}{*}{ PR57-058 } & $<1$ & PR57132 & 5.780 & - & - & - & - & 5.780 \\
\hline & $<2.5$ & PR57133 & 8.734 & - & - & - & - & 8.734 \\
\hline & $<5$ & PR57134 & 14.290 & PR57138 & 10.658 & PR57142 & 9.014 & 33.962 \\
\hline & $<5 \mathrm{~A}$ & PR57135 & 15.487 & PR57139 & 13.672 & PR57143 & 11.154 & 40.313 \\
\hline & $<10$ & PR57136 & 31.640 & PR57140 & 23.237 & PR57144 & 24.097 & 78.974 \\
\hline & $<15$ & PR57137 & 38.912 & PR57141 & 36.774 & PR57145 & 36.941 & 112.627 \\
\hline
\end{tabular}


Table 4. Mass on aerodynamically separated size-fractions - location three.

\begin{tabular}{|c|c|c|c|c|c|c|c|c|}
\hline \multirow{2}{*}{$\begin{array}{l}\text { Soil Sample } \\
\text { ID }\end{array}$} & \multirow{2}{*}{$\begin{array}{c}\text { Size- } \\
\text { Fraction, } \\
\text { Aerodynamic } \\
\text { Diameter, } \\
\mu \mathrm{m}\end{array}$} & \multicolumn{2}{|c|}{ Filter 1} & \multicolumn{2}{|c|}{ Filter 2} & \multicolumn{2}{|c|}{ Filter 3} & \multirow{2}{*}{$\begin{array}{c}\text { Sum Mass } \\
\mathrm{Mg}\end{array}$} \\
\hline & & ID & Mass, mg & ID & Mass, mg & ID & Mass, mg & \\
\hline \multirow[t]{6}{*}{ PR57-036 } & $<1$ & PR57146 & 6.804 & - & - & - & - & 6.804 \\
\hline & $<2.5$ & PR57147 & 8.838 & - & - & - & - & 8.838 \\
\hline & $<5$ & PR57148 & 13.314 & PR57152 & 11.380 & PR57156 & 12.936 & 37.630 \\
\hline & $<5 \mathrm{~A}$ & PR57149 & 13.813 & PR57153 & 13.061 & PR57157 & 14.743 & 41.617 \\
\hline & $<10$ & PR57150 & 30.777 & PR57154 & 26.636 & PR57158 & 27.280 & 84.693 \\
\hline & $<15$ & PR57151 & 36.244 & PR57155 & 35.841 & PR57159 & 33.042 & 105.127 \\
\hline \multirow[t]{6}{*}{ PR57-037 } & $<1$ & PR57160 & 5.593 & - & - & - & & 5.593 \\
\hline & $<2.5$ & PR57161 & 8.824 & - & - & - & - & 8.824 \\
\hline & $<5$ & PR57162 & 14.177 & PR57166 & 14.976 & PR57170 & 12.546 & 41.699 \\
\hline & $<5 \mathrm{~A}$ & PR57163 & 16.816 & PR57167 & 16.723 & PR57171 & 13.497 & 47.036 \\
\hline & $<10$ & PR57164 & 30.761 & PR57168 & 31.784 & PR57172 & 25.185 & 87.730 \\
\hline & $<15$ & PR57165 & 39.785 & PR57169 & 38.551 & PR57173 & 30.441 & 108.777 \\
\hline \multirow[t]{6}{*}{ PR57-039 } & $<1$ & PR57174 & 8.689 & - & - & - & - & 8.689 \\
\hline & $<2.5$ & PR57175 & 12.892 & - & - & - & - & 12.892 \\
\hline & $<5$ & PR57176 & 15.333 & PR57180 & 20.728 & PR57184 & 19.940 & 56.001 \\
\hline & $<5 \mathrm{~A}$ & PR57177 & 18.635 & PR57181 & 22.787 & PR57185 & 21.288 & 62.710 \\
\hline & $<10$ & PR57178 & 34.762 & PR57182 & 43.598 & PR57186 & 39.807 & 118.167 \\
\hline & $<15$ & PR57179 & 50.015 & PR57183 & 51.730 & PR57187 & 49.705 & 151.45 \\
\hline \multirow[t]{6}{*}{ PR57-040 } & $<1$ & PR57188 & 4.652 & - & - & - & - & 4.652 \\
\hline & $<2.5$ & PR57189 & 7.508 & - & - & - & - & 7.508 \\
\hline & $<5$ & PR57190 & 9.615 & PR57194 & 12.258 & PR57198 & 10.265 & 32.138 \\
\hline & $<5 \mathrm{~A}$ & PR57191 & 11.140 & PR57195 & 13.540 & PR57199 & 11.948 & 36.628 \\
\hline & $<10$ & PR57192 & 21.428 & PR57196 & 25.174 & PR57200 & 26.261 & 72.863 \\
\hline & $<15$ & PR57193 & 31.132 & PR57197 & 35.611 & PR57201 & 34.672 & 101.415 \\
\hline \multirow[t]{6}{*}{ PR57-057 } & $<1$ & PR57202 & 4.957 & - & - & - & - & 4.957 \\
\hline & $<2.5$ & PR57203 & 7.152 & - & - & - & - & 7.152 \\
\hline & $<5$ & PR57204 & 10.527 & PR57208 & 14.076 & PR57212 & 8.780 & 33.383 \\
\hline & $<5 \mathrm{~A}$ & PR57205 & 11.428 & PR57209 & 14.236 & PR57213 & 9.651 & 35.315 \\
\hline & $<10$ & PR57206 & 22.959 & PR57210 & 35.308 & PR57214 & 18.335 & 76.602 \\
\hline & $<15$ & PR57207 & 31.530 & PR57211 & 40.791 & PR57215 & 27.279 & 99.600 \\
\hline
\end{tabular}


composited by dissolving the filters and their contents in hydrofluoric and nitric acid. Alpha spectroscopy was used to quantify the americium, plutonium isotopes, and uranium isotopes on the composited filters. Method RICHRC-5057 was used for ${ }^{241} \mathrm{Am},{ }^{239+240} \mathrm{Pu}$, and ${ }^{238} \mathrm{Pu}$; method RICHRC-5030 was used for ${ }^{234} \mathrm{U},{ }^{235} \mathrm{U}$, and ${ }^{238} \mathrm{U}$. In all cases, the analyses were done at reduced volume because of the relatively small amount of mass on the filters. The alpha activities were counted for 100 minutes and referenced to tracers introduced to the samples. Activities were reported in $\mathrm{pCi} / \mathrm{g}$.

A total of 15 sets of filters were analyzed by alpha spectroscopy. The resulting activities in $\mathrm{pCi} / \mathrm{g}$ and $\mathrm{pCi} /$ filter are given in Tables 5 through 7 for ${ }^{239+240} \mathrm{Pu}$ and ${ }^{241} \mathrm{Am}$ for the $2.5 \mu \mathrm{m}$ and larger aerodynamically separated size-fractions. Those samples with activity below detection limits (one ${ }^{239+240} \mathrm{Pu}$ and two ${ }^{241} \mathrm{Am}$ ) are enclosed in parentheses on the Tables. Uranium was measured above detection limits in four samples as noted in footnotes in the Tables. The uranium activities will not be discussed further because of their low values and few samples on which they were found above detection limits. The activities are listed for particles in the composited filter sample with sizes less than the aerodynamic diameter listed at the top of each column. The mass presented on Tables 2, 3, and 4 for each particle size-range represents the mass collected on that filter as well as the cumulative mass of the finer soil particle fractions. In addition, the mass percentages of each particle size-fraction as a function of the total mass of each sample are provided as an additional means of evaluation of distribution of total inhalable particles and contaminants.

In a well-mixed suspension of particles in which the radioactive particles are uniformly distributed throughout the suspension chamber, the total activity on each filter should decrease as the particle size-fraction decreases, because each smaller fraction would contribute the same activity to larger fractions. Several samples, however, had more activity in the smaller size-fraction than in the larger ones. This could be the result of an inhomogeneous mixture of radioactive particles in the suspension, or for size-fractions with low mass, a single "hot particle" with attached plutonium or americium isotopes attached could similarly affect the results. The activities that were less than those for a smaller size range are underlined in the Tables. The inhomogeneity is particularly clear in several of the duplicate $5 \mu \mathrm{m}$ samples. The subsequent analysis has used the average of the $5 \mu \mathrm{m}$ samples.

The overall activity of soil particles in the inhalable size range of the three areas where samples were collected can be determined from the activities on the $15 \mu \mathrm{m}$ samples. These activities are also a measure of the total activity of particles in the inhalable size-ranges. The activities of ${ }^{239+240} \mathrm{Pu}$ in the $15-\mu \mathrm{m}$ samples range from 82 to $692 \mathrm{pCi} / \mathrm{g}$ for location one, from 818 to $2,940 \mathrm{pCi} / \mathrm{g}$ for location two, and from 189 to $1,600 \mathrm{pCi} / \mathrm{g}$ for location three.

The ratios of ${ }^{239+240} \mathrm{Pu}$ to ${ }^{241} \mathrm{Am}$ have been computed for each size-fraction for each soil sample and are given in Table 8. For all samples except those with activities less than the detection limit, the average ratio for all the size-fractions was 7.1, with a standard deviation of 10.8 and a range of 0.8 to 78.5 . The $95 \%$ confidence interval was 4.6 to 9.6. The averages for the different sizeranges had slight but not significant differences. The average ratio is reduced to 5.3 if the two large ratios, which appear to have much lower americium values than do other samples, are 
Table 5. Radioactivity on aerodynamically separated size-fractions - location one.

\begin{tabular}{|c|c|c|c|c|c|}
\hline \multirow{2}{*}{ Soil Sample ID } & \multirow{2}{*}{$\begin{array}{l}\text { Size-Fraction, } \\
\text { Aerodynamic } \\
\text { Diameter, } \mu \mathrm{m}\end{array}$} & \multicolumn{2}{|c|}{ Activity for ${ }^{239+240} \mathrm{Pu}$} & \multicolumn{2}{|c|}{ Activity for ${ }^{241} \mathrm{Am}$} \\
\hline & & $\mathrm{PCi} / \mathrm{g}$ & PCi/Sample & $\mathrm{PCi} / \mathrm{g}$ & PCi/Sample \\
\hline \multirow{5}{*}{ PR57-026 ${ }^{\mathrm{a}}$} & $<2.5$ & 65.4 & 0.4 & $(6.26)^{d}$ & $(0.04)$ \\
\hline & $<5$ & 94.7 & 2.1 & 16.2 & 0.4 \\
\hline & $<5 \mathrm{~A}$ & 98.1 & 3.6 & 15.9 & 0.6 \\
\hline & $<10$ & 261 & 18.1 & 43.9 & 3.0 \\
\hline & $<15^{\mathrm{a}}$ & 109 & $7.6^{\mathrm{e}}$ & 9.5 & 0.7 \\
\hline \multirow{5}{*}{ PR57-027 } & $<2.5$ & 162 & 0.6 & 50 & 0.2 \\
\hline & $<5^{\mathrm{b}}$ & 193 & 3.6 & 38.7 & 0.7 \\
\hline & $<5 \mathrm{~A}$ & 1390 & 31.3 & 254 & 5.7 \\
\hline & $<10$ & 281 & $\underline{11.2}$ & 71.4 & $\underline{2.9}$ \\
\hline & $<15$ & 330 & 19.1 & 52.9 & 3.1 \\
\hline \multirow[t]{5}{*}{ PR57-028 ${ }^{\mathrm{c}}$} & $<2.5$ & 380 & 3.6 & "57.8 & 0.6 \\
\hline & $<5^{\mathrm{c}}$ & 314 & 12.9 & 53.6 & 2.2 \\
\hline & $<5 \mathrm{~A}$ & 321 & 13.4 & 61.9 & 2.6 \\
\hline & $<10$ & 838 & 70.2 & 171 & 14.3 \\
\hline & $<15$ & 522 & $\underline{49.4}$ & 87.6 & $\underline{8.3}$ \\
\hline \multirow[t]{5}{*}{ PR57-029 } & $<2.5$ & $(6.54)$ & 0.1 & 88.1 & 0.9 \\
\hline & $<5$ & 54.2 & 1.6 & $(2.44)$ & $(0.07)$ \\
\hline & $<5 \mathrm{~A}$ & 70.1 & 2.7 & 11.5 & 0.5 \\
\hline & $<10$ & 139 & 9.0 & 45.4 & 2.9 \\
\hline & $<15$ & 81.6 & $\underline{3.9}$ & 16.1 & $\underline{0.8}$ \\
\hline \multirow[t]{5}{*}{ PR57-030 } & $<2.5$ & 158 & 0.8 & 47.1 & 0.2 \\
\hline & $<5$ & 259 & 6.4 & 60.5 & 1.5 \\
\hline & $<5 \mathrm{~A}$ & 379 & 12.1 & 67.7 & 2.2 \\
\hline & $<10$ & 439 & 23.6 & 92.3 & 5.0 \\
\hline & $<15$ & 692 & 47.3 & 120 & 8.2 \\
\hline
\end{tabular}

${ }^{\text {a }}{ }^{234} \mathrm{U}$ found above detection limit in $\langle 15 \mu \mathrm{m}$ fraction: $1.52 \mathrm{pCi} / \mathrm{g}, 0.11 \mathrm{pCi} / \mathrm{sample}$.

b ${ }^{238} \mathrm{U}$ found above detection limit in $<5 \mu \mathrm{m}$ fraction: $3.66 \mathrm{pCi} / \mathrm{g}, 0.070 \mathrm{pCi} / \mathrm{sample}$.

${ }^{c}{ }^{238} \mathrm{U}$ found above detection limit in $<5 \mu \mathrm{m}$ fraction: $1.60 \mathrm{pCi} / \mathrm{g}, 0.066 \mathrm{pCi} / \mathrm{sample}$.

${ }^{\mathrm{d}}$ Activities in ( ) are below detection limits for ${ }^{241} \mathrm{Am}$ or ${ }^{239+240} \mathrm{Pu}$.

${ }^{\mathrm{e}}$ Underlined activity indicates value less than in next smaller size-fraction. 
Table 6. Radioactivity on aerodynamically separated size-fractions - location two.

\begin{tabular}{|c|c|c|c|c|c|}
\hline \multirow{2}{*}{ Soil Sample ID } & \multirow{2}{*}{$\begin{array}{l}\text { Size-Fraction, } \\
\text { Aerodynamic } \\
\text { Diameter, } \mu \mathrm{m}\end{array}$} & \multicolumn{2}{|c|}{ Activity for ${ }^{239+240} \mathrm{Pu}$} & \multicolumn{2}{|c|}{ Activity for ${ }^{241} \mathrm{Am}$} \\
\hline & & $\mathrm{PCi} / \mathrm{g}$ & pCi/Sample & $\mathrm{pCi} / \mathrm{g}$ & pCi/Sample \\
\hline \multirow[t]{5}{*}{ PR57-031 } & $<2.5$ & 1300 & 9.4 & 222 & 1.6 \\
\hline & $<5$ & 3140 & 108.2 & 316 & 10.9 \\
\hline & $<5 \mathrm{~A}$ & 1500 & 53.7 & 314 & 11.4 \\
\hline & $<10$ & 3870 & 274.1 & 738 & 52.3 \\
\hline & $<15$ & 2940 & $262.6^{\mathrm{b}}$ & 501 & 44.8 \\
\hline \multirow[t]{5}{*}{ PR57-033 } & $<2.5$ & 630 & 6.2 & 86.6 & 0.9 \\
\hline & $<5$ & 562 & 20.8 & 101 & 3.7 \\
\hline & $<5 \mathrm{~A}$ & 757 & 30.8 & 155 & 6.3 \\
\hline & $<10$ & 1170 & 91.4 & 203 & 15.9 \\
\hline & $<15$ & 818 & $\underline{87.4}$ & 125 & $\underline{13.4}$ \\
\hline \multirow[t]{5}{*}{ PR57-034 } & $<2.5$ & 452 & 3.7 & 55.4 & 0.5 \\
\hline & $<5$ & 517 & 18.6 & 90.3 & 3.3 \\
\hline & $<5 \mathrm{~A}$ & 389 & 15.6 & 218 & 8.8 \\
\hline & $<10$ & 522 & 48.7 & 175 & 16.3 \\
\hline & $<15$ & 834 & 83.1 & 13.8 & $\underline{1.4}$ \\
\hline \multirow[t]{5}{*}{ PR57-035 } & $<2.5$ & 512 & 5.8 & 660 & 7.4 \\
\hline & $<5^{\mathrm{a}}$ & 9030 & 442.5 & 1490 & 73.0 \\
\hline & $<5 \mathrm{~A}$ & 706 & 36.9 & 519 & 27.1 \\
\hline & $<10$ & 1480 & $\underline{145.4}$ & 447 & 43.9 \\
\hline & $<15$ & 1860 & 248.1 & 23.7 & $\underline{3.5}$ \\
\hline \multirow[t]{5}{*}{ PR57-058 } & $<2.5$ & 1070 & 9.3 & 267 & 2.3 \\
\hline & $<5$ & 1610 & 54.7 & 316 & 10.7 \\
\hline & $<5 \mathrm{~A}$ & 3930 & 158.4 & 790 & 31.9 \\
\hline & $<10$ & 1260 & 99.5 & 195 & 15.4 \\
\hline & $<15$ & 2860 & 322.1 & 593 & 66.8 \\
\hline
\end{tabular}

${ }^{\text {a }}{ }^{238} \mathrm{U}$ found above detection limit in $<5 \mu \mathrm{m}$ fraction: $1.12 \mathrm{pCi} / \mathrm{g}, 0.055 \mathrm{pCi} / \mathrm{sample}$.

${ }^{\mathrm{b}}$ Underlined activity indicates value less than in next smaller size-fraction. 
Table 7. Radioactivity on aerodynamically separated size-fractions - location three.

\begin{tabular}{|c|c|c|c|c|c|}
\hline \multirow{2}{*}{ Soil Sample ID } & \multirow{2}{*}{$\begin{array}{l}\text { Size-Fraction, } \\
\text { Aerodynamic } \\
\text { Diameter, } \mu \mathrm{m}\end{array}$} & \multicolumn{2}{|c|}{ Activity for ${ }^{239+240} \mathrm{Pu}$} & \multicolumn{2}{|c|}{ Activity for ${ }^{241} \mathrm{Am}$} \\
\hline & & $\mathrm{PCi} / \mathrm{g}$ & pCi/Sample & $\mathrm{pCi} / \mathrm{g}$ & pCi/Sample \\
\hline \multirow[t]{5}{*}{ PR57-036 } & $<2.5$ & 315 & 2.8 & 54.1 & 0.5 \\
\hline & $<5$ & 731 & 27.5 & 156 & 5.6 \\
\hline & $<5 \mathrm{~A}$ & 621 & 25.8 & 119 & 5.0 \\
\hline & $<10$ & 1340 & 113.5 & 217 & 18.4 \\
\hline & $<15$ & 1600 & 168.2 & 220 & 23.1 \\
\hline \multirow[t]{5}{*}{ PR57-037 } & $<2.5$ & 166 & 1.5 & 38.1 & 0.3 \\
\hline & $<5$ & 233 & 9.7 & 43.8 & 1.8 \\
\hline & $<5 \mathrm{~A}$ & 119 & 5.6 & 34.4 & 1.6 \\
\hline & $<10$ & 434 & 38.1 & 69.4 & 6.1 \\
\hline & $<15$ & 436 & 47.4 & 89.9 & 9.8 \\
\hline \multirow[t]{5}{*}{ PR57-039 } & $<2.5$ & 82.7 & 1.1 & 14 & 0.2 \\
\hline & $<5$ & 88.6 & 5.0 & 17.6 & 1.0 \\
\hline & $<5 \mathrm{~A}$ & 105 & 6.6 & 21.1 & 1.3 \\
\hline & $<10$ & 183 & 21.6 & 35.9 & 4.2 \\
\hline & $<15$ & 189 & 28.6 & 34.3 & 5.2 \\
\hline \multirow[t]{5}{*}{ PR57-040 } & $<2.5$ & 190 & 1.4 & 23.3 & 0.2 \\
\hline & $<5$ & 270 & 8.7 & 51 & 1.6 \\
\hline & $<5 \mathrm{~A}$ & 260 & 9.5 & 44.5 & 1.6 \\
\hline & $<10$ & 623 & 45.4 & 112 & 8.2 \\
\hline & $<15$ & 487 & 49.4 & 90.3 & 9.2 \\
\hline \multirow[t]{5}{*}{ PR57-057 } & $<2.5$ & 161 & 1.2 & 32.3 & 0.2 \\
\hline & $<5$ & 250 & 8.3 & 54.4 & 1.8 \\
\hline & $<5 \mathrm{~A}$ & 211 & 7.5 & 46.1 & 1.6 \\
\hline & $<10$ & 347 & 26.6 & 77.3 & 5.9 \\
\hline & $<15$ & 350 & 34.9 & 75.2 & 7.5 \\
\hline
\end{tabular}

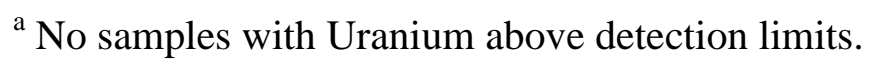


Table 8. Ratio of ${ }^{239+240} \mathrm{Pu}$ to ${ }^{241} \mathrm{Am}$ activity for aerodynamic size-fractions.

\begin{tabular}{|c|c|c|c|c|c|}
\hline \multirow{4}{*}{$\begin{array}{c}\text { Soil Sample } \\
\text { ID }\end{array}$} & \multicolumn{5}{|c|}{ Activity of ${ }^{241} \mathrm{Am}$ in $\mathrm{pCi} / \mathrm{g}$} \\
\hline & \multicolumn{5}{|c|}{ Aerodynamic Diameter in $\mu \mathrm{m}$} \\
\hline & \multirow{2}{*}{$\mathrm{d}<2.5$} & \multicolumn{2}{|c|}{$d<5$} & \multirow{2}{*}{$\mathrm{d}<10$} & \multirow{2}{*}{$\mathrm{d}<15$} \\
\hline & & First & Second & & \\
\hline PR57-026 & $(10.4)^{a}$ & 5.8 & 6.2 & 5.9 & 11.5 \\
\hline PR57-027 & 3.2 & 5.0 & 5.5 & 3.9 & 6.2 \\
\hline PR57-028 & 6.6 & 5.9 & 5.2 & 4.9 & 6.0 \\
\hline PR57-029 & $(0.1)^{a}$ & $(22.2)^{a}$ & 6.1 & 3.1 & 5.1 \\
\hline PR57-030 & 3.4 & 4.3 & 5.6 & 4.8 & 5.8 \\
\hline PR57-031 & 5.9 & 9.9 & 4.8 & 5.2 & 5.9 \\
\hline PR57-033 & 7.3 & 5.6 & 4.9 & 5.8 & 6.5 \\
\hline PR57-034 & 8.2 & 5.7 & 1.8 & 3.0 & 60.4 \\
\hline PR57-035 & 0.8 & 6.1 & 1.4 & 3.3 & 78.5 \\
\hline PR57-058 & 4.0 & 5.0 & 5.1 & 6.5 & 4.8 \\
\hline PR57-036 & 5.8 & 4.7 & 5.2 & 6.2 & 7.3 \\
\hline PR57-037 & 4.4 & 5.3 & 3.5 & 6.3 & 4.8 \\
\hline PR57-039 & 5.9 & 5.0 & 5.0 & 5.1 & 5.5 \\
\hline PR57-040 & 8.2 & 5.3 & 5.8 & 5.6 & 5.4 \\
\hline PR57-057 & 5.0 & 4.6 & 4.6 & 4.5 & 4.7 \\
\hline Average & 5.3 & 5.6 & 4.7 & 4.9 & 14.6 \\
\hline Std Dev & 21 & 1.4 & 1.4 & 1.2 & 22.6 \\
\hline Maximum & 8.2 & 9.9 & 6.2 & 6.5 & 78.5 \\
\hline Minimum & 0.8 & 4.3 & 1.4 & 3.0 & 4.7 \\
\hline Number & 13 & 14 & 15 & 15 & 15 \\
\hline \multirow{3}{*}{ All Size Ranges } & Average & 7.1 & \multicolumn{3}{|c|}{ 95\% Confidence Limits } \\
\hline & Std Dev & 10.8 & +95 & & .6 \\
\hline & Number & 72 & -95 & & .6 \\
\hline
\end{tabular}

${ }^{\text {a }}$ Ratios in ( ) have ${ }^{241} \mathrm{Am}$ or ${ }^{239+240} \mathrm{Pu}$ below detection limits - not used in averages.

not included in the average. Even the higher ratio of 7.1 is approximately three to four times lower than the ratio of ${ }^{239+240} \mathrm{Pu}$ to ${ }^{241} \mathrm{Am}$ found for soil samples at safety test sites on the Tonopah Test 
Range (TTR). Differences in the ratio of these isotopes at the Project 57 site compared to the TTR sites have been noted in previous studies, including Gilbert et al. (1975) and Kroodsma (1994), although methods used and ratios calculated varied from one study to another. Gilbert et al. (1975) calculated ratios based on over 150 samples collected over the entire aerial extent of the Project 57 plume, with samples collected to a depth of approximately $5 \mathrm{~cm}$. Plutonium to americium ratios in Gilbert et al. (1975) for Project 57 were "9 to 10" versus " 22 to 26 " at the TTR sites.

The activities in the size-intervals for aerodynamic diameters $<2.5 \mu \mathrm{m}$, from 2.5 to $5 \mu \mathrm{m}$, from 5 to $10 \mu \mathrm{m}$, and from 10 to $15 \mu \mathrm{m}$ have been computed from the mass and activities on filter samples. The activity in a particular size-interval was computed from

$$
\text { Activity }=\frac{a_{j} M_{j}-a_{j-1} M_{j-1}}{M_{j}-M_{j-1}}
$$

where $a_{j}$ is activity in the $\mathrm{jth}$ size-fraction, $\mathrm{M}_{\mathrm{j}}$ is mass in the $\mathrm{jth}$ size-fraction, and $\mathrm{j}-1$ is the next smaller size-interval. The computation assumes that the activity and mass associated with particles on the filters for the smaller size-fraction are similar to the activity and mass that size-fraction contributes to the filters for the larger size-fraction. The activities in the size-intervals are given in Table 9 for ${ }^{239+240} \mathrm{Pu}$ and in Table 10 for ${ }^{241} \mathrm{Am}$. The smallest size-interval considered here has a diameter less than 2.5- $\mu \mathrm{m}$ computations. These filters had masses for the $<10 \mu \mathrm{m}$ and $<15 \mu \mathrm{m}$ sizefractions that were nearly equal, while the measured activity was higher on the $<10 \mu \mathrm{m}$ filters than on the $<15 \mu \mathrm{m}$ filters. Negative values for the 10 - to15- $\mu \mathrm{m}$ interval may be attributed to the inhomogeneous mixture of soil and radionuclides that were introduced to the suspension chamber, errors in the measurement of small amounts of radioactivity, and the possible effects of a "hot particle" on activity distribution, particularly for filters where the mass and total activity were low.

The data indicate that there is a correlation between the aerodynamically separated particle size-fractions and the activity on them, although it is statistically more significant for plutonium than americium isotopes. The means of the ${ }^{239+240} \mathrm{Pu}$ activities have been computed for the samples that did not have negative values and are included in Table 9. The mean activity increased as the particle size increased. The paired t-Tests in Table 11 show statistically significant increases in activity between the $<2.5 \mu \mathrm{m}$ and $2.5-5 \mu \mathrm{m}$ intervals (at the $3.4 \%$ level) and the $2.5-5 \mu \mathrm{m}$ and 5-10 $\mu \mathrm{m}$ intervals (at the $1.3 \%$ level). The increase between the 5-10 $\mu \mathrm{m}$ and 10-15 $\mu \mathrm{m}$ interval had a significance level of $12.5 \%$ and would not be considered statistically significant. The means of the ${ }^{241} \mathrm{Am}$ activities have been computed for the seven sets that did not have negative values and are included in Table 10. The ${ }^{241} \mathrm{Am}$ activities also tended to increase as the particle size increased, but, as shown in Table 11, no increase was statistically significant.

The duplicate soil samples resulted in some differences in activity, although the comparison between PR57-040 and its duplicate PR57-057 was better than the comparison between PR57-035 and PR57-058. The average percent difference between the ${ }^{239+240} \mathrm{Pu}$ activity on the composite filters for PR57-040 and PR57-057 was -7\% with a standard deviation of 52\%. A paired t-Test for these samples gave a small t-Statistic of 0.761 for a difference that would be statistically significant at the 48\% level, which shows no significant difference between the PR57-040 and PR57-057 samples. With the two largest activities on the $5 \mu \mathrm{m}$ filters not included, the average percent difference between the ${ }^{239+240} \mathrm{Pu}$ activity on the composite filters for PR57-035 and PR57-058 was 
$31 \%$ with a standard deviation of $47 \%$. A paired t-Test for these samples gave a t-Statistic of 1.514 for a difference that would have been statistically significant at the $21 \%$ level, which shows the samples were different but at a low statistical level. The differences in the duplicate samples are one evidence of the extreme variability in the distribution of radionuclides within safety test contaminant plumes.

Table 9. Activity of ${ }^{239+240} \mathrm{Pu}$ for aerodynamic size-fractions.

\begin{tabular}{|c|c|c|c|c|}
\hline \multirow{3}{*}{$\begin{array}{l}\text { Soil Sample } \\
\text { ID }\end{array}$} & \multicolumn{4}{|c|}{ Activity of ${ }^{239+240} \mathrm{Pu}$ in $\mathrm{pCi} / \mathrm{g}$} \\
\hline & \multicolumn{4}{|c|}{ Aerodynamic Diameter in $\mu \mathrm{m}$} \\
\hline & $\mathrm{d}<2.5$ & $2.5<\mathrm{d}<5$ & $5<d<10$ & $10<\mathrm{d}<15$ \\
\hline \multicolumn{5}{|l|}{ Location One } \\
\hline PR57-026 & 65 & 106 & 383 & -17559 \\
\hline PR57-027 & 162 & 201 & 359 & 439 \\
\hline PR57-028 & 380 & 298 & 1348 & -1878 \\
\hline PR57-029 & 7 & 86 & 222 & 298 \\
\hline PR57-030 & 158 & 364 & 565 & 1617 \\
\hline \multicolumn{5}{|l|}{ Location Two } \\
\hline PR57-031 & 1300 & 2503 & 5411 & -620 \\
\hline PR57-033 & 630 & 676 & 1671 & -137 \\
\hline PR57-034 & 452 & 449 & 572 & 5418 \\
\hline PR57-035 & 512 & 759 & 2358 & 2922 \\
\hline PR57-058 & 1070 & 1797 & 996 & 6615 \\
\hline \multicolumn{5}{|l|}{ Location Three } \\
\hline PR57-036 & 315 & 776 & 1926 & 2678 \\
\hline PR57-037 & 166 & 174 & 702 & 444 \\
\hline PR57-039 & 83 & 101 & 270 & 210 \\
\hline PR57-040 & 190 & 286 & 943 & 140 \\
\hline PR57-057 & 161 & 248 & 442 & 360 \\
\hline \multicolumn{5}{|c|}{ Summary for Locations without Negative Activities } \\
\hline Average & 377 & 592 & 1211 & 1922 \\
\hline Std Dev & 375 & 699 & 1330 & 2269 \\
\hline Number & 15 & 15 & 15 & 11 \\
\hline
\end{tabular}


Table 10. Activity of ${ }^{241}$ Am for aerodynamic size-fractions.

\begin{tabular}{|c|c|c|c|c|}
\hline \multirow{3}{*}{$\begin{array}{c}\text { Soil Sample } \\
\text { ID }\end{array}$} & \multicolumn{4}{|c|}{ Activity of ${ }^{241} \mathrm{Am}$ in $\mathrm{pCi} / \mathrm{g}$} \\
\hline & \multicolumn{4}{|c|}{ Aerodynamic Diameter in $\mu \mathrm{m}$} \\
\hline & $\mathrm{d}<2.5$ & $2.5<\mathrm{d}<5$ & $5<d<10$ & $10<d<15$ \\
\hline \multicolumn{5}{|l|}{ Location One } \\
\hline PR57-026 & 6 & 19 & 65 & -3989 \\
\hline PR57-027 & 50 & 203 & -18 & 12 \\
\hline PR57-028 & 58 & 58 & 282 & -546 \\
\hline PR57-029 & 88 & -14 & 97 & 127 \\
\hline PR57-030 & 47 & 69 & 123 & 221 \\
\hline \multicolumn{5}{|l|}{ Location Two } \\
\hline PR57-031 & 222 & 339 & 1155 & -406 \\
\hline PR57-033 & 87 & 144 & 276 & -87 \\
\hline PR57-034 & 55 & 101 & 228 & -2354 \\
\hline PR57-035 & 660 & 480 & 365 & -1160 \\
\hline PR57-058 & 267 & 333 & 104 & 1527 \\
\hline \multicolumn{5}{|l|}{ Location Three } \\
\hline PR57-036 & 54 & 160 & 286 & 232 \\
\hline PR57-037 & 38 & 39 & 101 & 175 \\
\hline PR57-039 & 14 & 21 & 53 & 29 \\
\hline PR57-040 & 23 & 54 & 170 & 35 \\
\hline PR57-057 & 32 & 55 & 99 & 68 \\
\hline \multicolumn{5}{|c|}{ Summary for Locations without Negative Activities } \\
\hline Average & 113 & 148 & 243 & 302 \\
\hline Std Dev & 168 & 142 & 280 & 501 \\
\hline Number & 15 & 14 & 14 & 8 \\
\hline
\end{tabular}


Table 11. t-Test for activity of ${ }^{239+240} \mathrm{Pu}$ and ${ }^{241} \mathrm{Am}$ for aerodynamic size-fractions. Comparisons of samples without negative activities.

\begin{tabular}{|c|c|c|c|}
\hline & \multicolumn{3}{|c|}{$\begin{array}{l}\text { Comparison Groups } \\
\text { Aerodynamic Diameter in } \mu \mathrm{m}\end{array}$} \\
\hline & $\begin{array}{l}<2.5 \text { vs. } \\
2.5 \text { to } 5\end{array}$ & $\begin{array}{l}2.5 \text { to } 5 \text { vs. } \\
5 \text { to } 10\end{array}$ & $\begin{array}{l}5 \text { to } 10 \mathrm{vs} \text {. } \\
10 \text { to } 15\end{array}$ \\
\hline \multicolumn{4}{|l|}{${ }^{239+240} \mathrm{Pu}$} \\
\hline Degrees of freedom & 14 & 14 & 10 \\
\hline $\mathrm{t}$-Statistic for paired samples & 2.342 & 2.846 & 1.673 \\
\hline $\begin{array}{c}\text { Probability of rejecting null } \\
\text { hypothesis }\end{array}$ & 0.034 & 0.013 & 0.125 \\
\hline \multicolumn{4}{|l|}{${ }^{241} \mathrm{Am}$} \\
\hline Degrees of freedom & 13 & 12 & 7 \\
\hline t-Statistic for paired samples & 1.594 & 1.650 & 0.957 \\
\hline $\begin{array}{c}\text { Probability of rejecting null } \\
\text { hypothesis }\end{array}$ & 0.135 & 0.125 & 0.370 \\
\hline
\end{tabular}




\section{Sieved Size Fractions - Gamma Spectroscopy}

The sieved fractions were analyzed by gamma spectroscopy for ${ }^{241} \mathrm{Am}$ at UNLV's Health Physics Department with a gamma radiation counter using a High Purity Germanium detector. A portion (14 or 28 grams) of each sieved fraction was weighed on an Ohaus Cent-O-Gram fourbeam, hanging-pan balance that was located in the hood in the Radiation Protection Laboratory. Each portion was placed in a plastic dish that was covered, sealed, and transported to the Health Physics Department. The quantity of mass and the dish size were chosen to fit into the counter and to give the proper depth of sample for optimal counting. The duration of most counting periods was 600 seconds with a few samples counted for longer periods. The detected radionuclides included ${ }^{241} \mathrm{Am}$ in all samples and ${ }^{224} \mathrm{Ra}$ and ${ }^{40} \mathrm{~K}$ in a few samples. Only the values for ${ }^{241} \mathrm{Am}$ are presented and analyzed herein.

Table 12 lists the ${ }^{241} \mathrm{Am}$ activities in the sample intervals for physical diameters $<38 \mu \mathrm{m}, 38$ to $75 \mu \mathrm{m}, 75$ to $150 \mu \mathrm{m}, 150$ to $300 \mu \mathrm{m}, 300$ to $600 \mu \mathrm{m}$, and $>600 \mu \mathrm{m}$. The relation among the sieved samples from the three locations and the individual samples was similar to that of the aerodynamically separated samples. The highest activities were found for location two; the activity at location three slightly exceeded that at location one. The individual soil samples with the highest alpha activities also had the highest gamma activities; the individual soil samples with the lowest alpha activities also had the lowest gamma activities. A few soil samples had one or more sizeintervals with much higher activity than is found in other size-intervals for the sample, which may be indicative of the inhomogeneity of the mixture of radionuclides in some of the samples. However, in general, the results suggest from the sieved fractions that the plutonium and americium show similar distributions as a function of particle size and that there has not been significant relocation of one versus the other over time.

The mean activity for the sieved fractions decreased with increasing particle size for all but the 150 to $300 \mu \mathrm{m}$ size interval. One soil sample, PR57-058, had a high ${ }^{241} \mathrm{Am}$ activity in the 150 to $300 \mu \mathrm{m}$ range. With the PR57-058 sample not included in the averages, the mean activity decreased with increasing particle size for all sizes. Paired t-Tests confirm that, without PR57-058, the decreases in the means with increasing particle size were highly statistically significant for the $<38 \mu \mathrm{m}$ to $38-75 \mu \mathrm{m}$ interval, for the $75-15 \mu \mathrm{m}$ to $150-300 \mu \mathrm{m}$ interval, and for the $150-300 \mu \mathrm{m}$ to $300-600 \mu \mathrm{m}$ interval. The decrease for the $300-600 \mu \mathrm{m}$ to $>600 \mu \mathrm{m}$ interval was slightly less significant but still at the $3.5 \%$ level. The decrease in the mean activity between the 38 to $75 \mu \mathrm{m}$ to 75 to $150 \mu \mathrm{m}$ interval had a significance level of $7.2 \%$, only slightly statistically significant.

The total amount of ${ }^{241} \mathrm{Am}$ in each sieved sample cannot be determined, because the sieved fractions were not weighed when the separations were done. Similarly, the total activity of the soil samples cannot be determined, particularly since plutonium analysis was not done on them. The sieved fractions were not originally intended to be analyzed. The sieved fractions were analyzed only after a gross gamma survey meter indicated relatively high activities in some of the sieved fractions. Work by Papelis et al. (1996) on six Project 57 samples used to evaluate soil volume reduction technologies showed an average of $54.9 \%$ of the Pu activity is associated with particles less than $38 \mu \mathrm{m}$. However, the standard deviation of 44.1 indicates the variability between samples. 
Table 12. Activity of ${ }^{241} \mathrm{Am}$ for sieved size-fractions.

\begin{tabular}{|c|c|c|c|c|c|c|}
\hline \multirow{3}{*}{$\begin{array}{c}\text { Soil Sample } \\
\text { ID }\end{array}$} & \multicolumn{6}{|c|}{ Activity of ${ }^{241} \mathrm{Am}$ in $\mathrm{pCi} / \mathrm{g}$} \\
\hline & \multicolumn{6}{|c|}{ Physical Diameter in $\mu \mathrm{m}$} \\
\hline & $<38$ & $38<d<75$ & $75<\mathrm{d}<150$ & $150<d<300$ & $300<d<600$ & $d>600$ \\
\hline \multicolumn{7}{|l|}{ Location One } \\
\hline PR57-026 & 423 & 189 & 44 & 15 & 9 & 3 \\
\hline PR57-027 & 323 & 492 & 107 & 34 & 12 & 6 \\
\hline PR57-028 & 551 & 570 & 71 & 31 & 29 & 3 \\
\hline PR57-029 & 279 & 223 & 15 & 7 & 7 & 1 \\
\hline PR57-030 & 390 & 597 & 42 & 14 & 22 & 4 \\
\hline \multicolumn{7}{|l|}{ Location Two } \\
\hline PR57-031 & 1491 & 1056 & 421 & 398 & 98 & 120 \\
\hline PR57-033 & 860 & 147 & 151 & 76 & 39 & 9 \\
\hline PR57-034 & 701 & 272 & 126 & 128 & 23 & 18 \\
\hline PR57-035 & 1328 & 204 & 163 & 192 & 50 & 17 \\
\hline PR57-058 & 2632 & 508 & 183 & 1735 & 81 & 17 \\
\hline \multicolumn{7}{|c|}{ Location Three } \\
\hline PR57-036 & 1280 & 502 & 298 & 39 & 42 & 8 \\
\hline PR57-037 & 565 & 374 & 86 & 23 & 18 & 6 \\
\hline PR57-039 & 177 & 339 & 124 & 18 & 12 & 13 \\
\hline PR57-040 & 789 & 445 & 132 & 27 & 23 & 4 \\
\hline PR57-057 & 325 & 474 & 60 & 23 & 15 & 4 \\
\hline \multicolumn{7}{|c|}{ Summary for All Locations } \\
\hline Average & 808 & 426 & 135 & 184 & 32 & 15 \\
\hline $\begin{array}{c}\text { Standard } \\
\text { Deviation }\end{array}$ & 649 & 228 & 106 & 441 & 27 & 29 \\
\hline Number & 15 & 15 & 15 & 15 & 15 & 15 \\
\hline
\end{tabular}


Table 13. t-Test for activity of ${ }^{241} \mathrm{Am}$ for sieved size-fractions.

\begin{tabular}{|c|c|c|c|c|c|}
\hline & \multicolumn{5}{|c|}{$\begin{array}{c}\text { Comparison Groups } \\
\text { Physical Diameter in } \mu \mathrm{m}\end{array}$} \\
\hline & $\begin{array}{l}38 \text { to } 75 \text { vs. } \\
<38\end{array}$ & $\begin{array}{c}75 \text { to } 150 \text { vs. } \\
38 \text { to } 150\end{array}$ & $\begin{array}{c}150 \text { to } 300 \text { vs. } \\
75 \text { to } 150\end{array}$ & $\begin{array}{c}300 \text { to } 600 \text { vs. } \\
150 \text { to } 300\end{array}$ & $\begin{array}{l}>600 \text { vs. } \\
300 \text { to } 600\end{array}$ \\
\hline \multicolumn{6}{|l|}{ All Samples } \\
\hline Degrees of freedom & 14 & 14 & 14 & 14 & 14 \\
\hline $\begin{array}{l}\text { t-Statistic for paired } \\
\text { samples }\end{array}$ & 2.376 & 6.165 & 0.450 & 1.390 & 3.256 \\
\hline $\begin{array}{c}\text { Probability of rejecting } \\
\text { null hypothesis }\end{array}$ & 0.032 & 0.000 & 0.659 & 0.186 & 0.006 \\
\hline \multicolumn{6}{|c|}{ Without Sample Number 58} \\
\hline Degrees of freedom & 13 & 13 & 13 & 13 & 13 \\
\hline $\begin{array}{l}\text { t-Statistic for paired } \\
\text { samples }\end{array}$ & 2.360 & 5.695 & 3.145 & 1.955 & 3.248 \\
\hline $\begin{array}{c}\text { Probability of rejecting } \\
\text { null hypothesis }\end{array}$ & 0.035 & 0.000 & 0.008 & 0.072 & 0.006 \\
\hline
\end{tabular}




\subsection{CONCLUSIONS}

Soil samples were collected specifically for separation by the SSPSS at three general locations in the deposited Project 57 plume, the projected radioactivity of which ranged from 100 to $600 \mathrm{pCi} / \mathrm{g}$. Samples were collected from this range of the plume because it represents what are anticipated to be residual contaminant levels after corrective action at the site. As a consequence, results of the SSPSS analysis can be used for dose-level and corrective action-level determinations for future land-use scenarios. Higher activity soils were also not considered because of restrictions on the amount of radioactive material that UNLV was licensed to have in its possession. Soil samples were collected at five sites for each of the three locations. At each sample site, vegetation and other debris were cleared and soil was collected to a depth of approximately $8 \mathrm{~cm}$, placed in a 2-liter container, and marked with a sample identification number. At two of the sample sites, a second soil sample was collected to serve as a duplicate sample.

The soil samples were sieved into six size-fractions with physical diameters greater than 600 $\mu \mathrm{m}, 300$ to $600 \mu \mathrm{m}, 150$ to $300 \mu \mathrm{m}, 75$ to $150 \mu \mathrm{m}, 38$ to $75 \mu \mathrm{m}$, and less than $38 \mu \mathrm{m}$. The $38 \mu \mathrm{m}$ fraction was further separated by aerodynamic sizing into five size-fractions with aerodynamic diameters less than $1 \mu \mathrm{m}$, less than $2.5 \mu \mathrm{m}$, less than $5 \mu \mathrm{m}$, less than $10 \mu \mathrm{m}$, and less than $15 \mu \mathrm{m}$. From a dose perspective, particles less than $15 \mu \mathrm{m}$ are considered potentially inhalable. No additional analysis was performed on the particle size-fraction between $15 \mu \mathrm{m}$ and $38 \mu \mathrm{m}$. Quanterra Environmental Services, Richland Laboratory, analyzed the aerodynamically separated particle samples for plutonium, americium, and uranium using alpha spectroscopy. Uranium was found on single size-fractions in only four samples in low levels ranging from 1.12 to $3.72 \mathrm{pCi} / \mathrm{g}$ (0.06 to $0.11 \mathrm{pCi}$ total activity) and was not considered in further analysis. UNLV's Department of Health Physics analyzed the sieved size-fractions for americium using gamma spectroscopy. Quality assurance/quality control included steps during sieving operations to minimum loss of material during shaking and during transfer from the sieves for weighing and analysis. For filter SSPSS operations and filter analysis, steps included the simultaneous collection of two $<5 \mu \mathrm{m}$ samples, random weighing of a control set of filters and with other calibration weights, leak tests and flow rate checks of the SSPSS equipment during operation, and a 5 to 10 minute "settling" period before filters were removed to help ensure that no particles remained in suspension.

For the aerodynamically separated size-fractions, analyzed activities for ${ }^{239+240} \mathrm{Pu}$ ranged from 54 to $1,390 \mathrm{pCi} / \mathrm{g}$ for location one, from 450 to $9,000 \mathrm{pCi} / \mathrm{g}$ for location two, and from 83 to $1,600 \mathrm{pCi} / \mathrm{g}$ for location three. The analyzed activities for ${ }^{241} \mathrm{Am}$ ranged from 10 to $254 \mathrm{pCi} / \mathrm{g}$ for location one, from 14 to $1,490 \mathrm{pCi} / \mathrm{g}$ for location two, and from 14 to $220 \mathrm{pCi} / \mathrm{g}$ for location three. Several soil samples had more activity in the smaller size-fractions than in the larger ones, which suggests that radioactive particles may not have been uniformly distributed in the SSPSS suspension chamber during particle separation.

The average ratio of ${ }^{239+240} \mathrm{Pu}$ to ${ }^{241} \mathrm{Am}$ for the aerodynamically separated samples analyzed by alpha spectroscopy for all size-fractions was 5.4 with a standard deviation of 1.5 and a range of 1.8 to 11.5 , with the $95 \%$ confidence interval range being 5.1 to 5.8. The averages for the different size-ranges had slight but not significant differences. The ratio of 5.4 is three to four times lower than the ratio of ${ }^{239+240} \mathrm{Pu}$ to ${ }^{241} \mathrm{Am}$ found for soil samples at safety tests on the TTR. The differences in the ratios for these isotopes compared to the TTR sites were also noted in research by the Nevada Applied Ecology Group at Project 57 (Gilbert et al., 1975). 
The data indicate that there is a correlation between the aerodynamically separated particle size-fraction and its activity, although it is statistically more significant for plutonium than americium isotopes. The activities in the size-intervals for aerodynamic diameters $<2.5 \mu \mathrm{m}$, from 2.5 to $5 \mu \mathrm{m}$, from 5 to $10 \mu \mathrm{m}$, and from 10 to $15 \mu \mathrm{m}$ were determined from the mass and activities on filter samples. The mean activity of ${ }^{239+240} \mathrm{Pu}$ on the aerodynamically separated samples increased as the particle size increased: $377 \mathrm{pCi} / \mathrm{g}$ for the $<2.5 \mu \mathrm{m}$ interval, $592 \mathrm{pCi} / \mathrm{g}$ for the 2.5 to $5 \mu \mathrm{m}$ interval, $1211 \mathrm{pCi} / \mathrm{g}$ for 5 to $10 \mu \mathrm{m}$ interval, and $1922 \mathrm{pCi} / \mathrm{g}$ for the 10 to $15 \mu \mathrm{m}$ interval. Paired t-Tests show statistically significant increases in ${ }^{239+240} \mathrm{Pu}$ activity between the $<2.5 \mu \mathrm{m}$ and 2.5-5 $\mu \mathrm{m}$ intervals (at the 3.4\% level) and the $2.5-5 \mu \mathrm{m}$ and 5-10 $\mu \mathrm{m}$ intervals (at the $1.3 \%$ level). The increase between the 5-10 $\mu \mathrm{m}$ and 10-15 $\mu \mathrm{m}$ interval had a significance level of $12.5 \%$ and would not be considered statistically significant. The means of the ${ }^{241} \mathrm{Am}$ activities in the $<2.5 \mu \mathrm{m}$, from 2.5 to $5 \mu \mathrm{m}$, from 5 to $10 \mu \mathrm{m}$, and from 10 to $15 \mu \mathrm{m}$ size-intervals were also computed. The ${ }^{241} \mathrm{Am}$ activities also tended to increase as the particle size increased, but no increase was statistically significant.

The activities of ${ }^{241} \mathrm{Am}$ in the sieved sample measured by gamma spectroscopy, particularly in the small size-intervals, are higher (range of 8.4 to $2630 \mathrm{pCi} / \mathrm{g}$ ) than might be expected given the activities of ${ }^{241} \mathrm{Am}$ and ${ }^{239+240} \mathrm{Pu}$ in the aerodynamically separated samples. If the same ratio of plutonium to americium holds as for the aerodynamically separated size-fractions, the plutonium activity of the sieved samples would be about five times the americium activity. The plutonium activity in the $<38 \mu \mathrm{m}$ size-range would then range from 800 to $13,000 \mathrm{pCi} / \mathrm{g}$. The results of the gamma counting and subsequent calculations have been checked and determined to be correct to within the uncertainties of the measurement. A large amount of plutonium associated with particles having aerodynamic diameters greater than $15 \mu \mathrm{m}$ (a diameter of about $3 \mu \mathrm{m}$ for a plutonium particle or $5 \mu \mathrm{m}$ for a plutonium oxide particle) and physical sizes less than $38 \mu \mathrm{m}$ could result in the high activities in this size range.

In general, the relation among the sieved samples from the three locations is similar to that of the aerodynamically separated samples. The highest activities were found for location two; the activity at location three slightly exceeded that at location one. The individual soil samples with the highest alpha activities also had the highest gamma activities; the individual soil samples with the lowest alpha activities also had the lowest gamma activities. A few soil samples had one or more size-intervals with much higher activity than is found in other size-intervals for the sample, which may be indicative of the inhomogeneity of the mixture of radionuclides in some of the samples. However, in general, the results suggest than plutonium and americium are similarly distributed in the soil, both in the potentially inhalable size range and in larger size particle fractions.

The total amount of ${ }^{241} \mathrm{Am}$ in each sieved sample cannot be determined, because the sieved fractions were not weighed when the separations were done. Similarly, the total activity of the soil samples cannot be determined since plutonium analysis was not performed on the sieved fractions. The sieved fractions were not originally intended to be analyzed. The sieved fractions were analyzed only after a survey meter indicated relatively high activities in some of the sieved fractions. Previous work at the site (Papelis et al., 1996) indicated slightly more than $50 \%$ of the $\mathrm{Pu}$ activity is associated with particles less than $38 \mu \mathrm{m}$, but with considerable variability between samples. In any future, work with the SSPSS, the total weight soil sample, the weight of the part that 
is sieved, and the weights of each sieved size-fraction should be determined. The principal benefit would be to more fully understand total activity distribution among all soil particle sizes.

\subsection{REFERENCES}

Bechtel Nevada, 1997. Transfer of aerial survey data to the U.S. Department of Energy, Nevada Operations Office. Las Vegas, NV: Remote Sensing Laboratory. Transmittal letter.

Bowen, J.L., V. Hodge and R. Gonzalez, 1998. Plutonium measurements in soil at Clean Slate 1 following corrective action using the Suspended Soil Particle Sizing System (SSPSS). DRI Document Number 6357-683-7564.1F1, Submitted to U.S. Department of Energy, Nevada Field Office, Las Vegas, Nevada 89193-8518, June 8, 1998.

Chow, J.C., J.G. Watson, J.E. Houck, L.C. Pritchett, C.F. Rogers, C.A. Frazier, R.T. Egami and B.M. Ball, 1994. A laboratory resuspension chamber to measure fugitive dust size distributions and chemical compositions. Atmos. Environ., 28, 3463-3481.

Friedlander, S.K., 1977. Smoke, Dust and Haze - Fundamentals of Aerosol Behavior. John Wiley and Sons, New York, NY, 317 pp.

Gilbert, R.O., L.L. Eberhardt, E.B. Fowler, E.M. Romney, E.H. Essington, and J.E. Kinnear, 1975. Statistical analysis of $\mathrm{Pu}-239,240$ and Am-241 contamination of soils and vegetation on Nevada Applied Ecology Group study sites, in The Radioecology of Plutonium and Other Transuranics in Desert Environments, M.G. White and P.B. Dunaway (Eds), U.S. Energy Research and Development Administration Report NVO-181, pp. 423-430, Nevada Operations Office, Las Vegas.

Kroodsma, Travis, 1994. Radiation Dose Assessment for Plutonium Contamination at Area 13 of the Nevada Test Site Using Nevada Applied Ecology Group Data and the RESRAD Code. M.S. Thesis, University of Tennessee, Knoxville, TN, 164 pp.

Papelis, C., R.L. Jacobson, F.L. Miller, and L.K. Shaulis, 1996. Evaluation of technologies for volume reduction of plutonium-contaminated soils from the Nevada Test Site. Desert Research Institute, Publication No. 45139, DOE/NV/10845-57.

Whitby, K.T., 1978. The physical characteristics of sulfur particles. Atmos. Environ., 12, 135159. 